\title{
Insight into Pretreatment Methods of Lignocellulosic Biomass to Increase Biogas Yield: Current State, Challenges, and Opportunities
}

\author{
Javier Ulises Hernández-Beltrán $\mathbb{D}^{\mathbb{D}}$, Inty Omar Hernández-De Lira, Mónica María Cruz-Santos, \\ Alexia Saucedo-Luevanos, Fernando Hernández-Terán and Nagamani Balagurusamy *(D) \\ Laboratorio de Biorremediación, Facultad de Ciencias Biológicas, Universidad Autónoma de Coahuila, \\ Torreón 27000, Coahuila, Mexico \\ * Correspondence: bnagamani@uadec.edu.mx; Tel.: +52-871-7571-785
}

Received: 29 July 2019; Accepted: 26 August 2019; Published: 6 September 2019

\begin{abstract}
Lignocellulosic biomass is recalcitrant due to its heterogeneous structure, which is one of the major limitations for its use as a feedstock for methane production. Although different pretreatment methods are being used, intermediaries formed are known to show adverse effect on microorganisms involved in methane formation. This review, apart from highlighting the efficiency and limitations of the different pretreatment methods from engineering, chemical, and biochemical point of views, will discuss the strategies to increase the carbon recovery in the form of methane by way of amending pretreatments to lower inhibitory effects on microbial groups and by optimizing process conditions.
\end{abstract}

Keywords: lignocellulosic biomass; pretreatment methods; limitations; anaerobic digestion; biogas

\section{Introduction}

Rapid growth in human population, biodiversity, and natural resources losses, environmental pollution, and climate change [1] have led researchers and policy makers to pay attention to sustainable energy policies for reduction the effect of greenhouse gas emissions [2]. In addition, depletion of fossil reserves is occurring at faster rate as there is an accelerated increase in the consumption of fossil fuels due to industrialization and motorization of the world [3].

Today, fossil fuels still serve as the primary global energy resource and account for more than $88 \%$ of the primary energy usage [4] and their combustion result in the emission of greenhouse gases, especially $\mathrm{CO}_{2}$ [5]. Thus, replacing fossil fuels with renewable sources of energy provides the opportunity to tackle these phenomena by limiting the increase of global temperature [6]. Renewable energy is defined as the contribution of renewable energies to the total supply of primary energy, including the equivalent of primary energy from hydroelectric sources (excluding storage by pumping), geothermal, solar, wind, tidal, and wave energy. It also includes the energy derived from solid biofuels, biodiesel, other liquid biofuels, biogas and the renewable fraction of municipal waste. Likewise, biofuels are defined as fuels derived directly or indirectly from biomass [7]. Biomass as referred as the fourth largest energy source (after coal, oil, and natural gas), and the largest and most important renewable energy option today and can be used to produce different forms of energy [8]. Biomass has the advantage to be considered as carbon neutral because the quantity of $\mathrm{CO}_{2}$ released during combustion is the same as that absorbed by the plant during photosynthesis [9]. The largest potential feedstock for bioenergy production is lignocellulosic biomass, which represents the most economical and highly renewable natural source in the world. 


\subsection{Classification of Types of Lignocellulose}

Lignocellulosic biomass is a biological material obtained from living or recently living organisms [7]. A brief summary of different types of lignocellulosic residues generated in Mexico are presented in Table 1.

Table 1. A brief summary of lignocellulosic residues generated in Mexico.

\begin{tabular}{cc}
\hline Lignocellulosic Residues & Amounts of Residues Produced per Year in México \\
\hline Straw from rice, wheat, soy, oats \& corn & $78,534,119.08$ tons \\
Stump, sawdust, plant \& tree branches & 8.2 million $\mathrm{m}^{3}$ as rolls \\
Sugar beet \& Sugarcane residues & $16,935,954.03$ tons \\
Urban solid residues & 102,895 tons \\
Municipal sewage sludge & 7200 million $\mathrm{m}^{3}$ \\
Residues from nuts, pistachios, peanuts \& pine nuts & $74,249.575$ tons \\
Manure from cows, pigs, poultry, turkey \& sheep & $142,139,944.5$ tons \\
\hline
\end{tabular}

The amount of residues produced per year in Mexico were obtained from the data on crop production, which was multiplied with the coefficient of waste generated for each residue. Data on production was consulted from the web portal of Agri-Food and Fisheries Information Service (SIAP), Government of Mexico [10].

\subsection{Chemical Composition of Lignocellulosic Biomass}

During the growth, plant biomass produce primary and secondary walls; primary wall is involved in structural functions like protection, signal transduction, and interactions with neighboring cells; besides, it contains low proportion of cellulose but a greater presence of pectin, meanwhile, secondary wall is composed principally of lignocellulose [11] (see Figure 1).
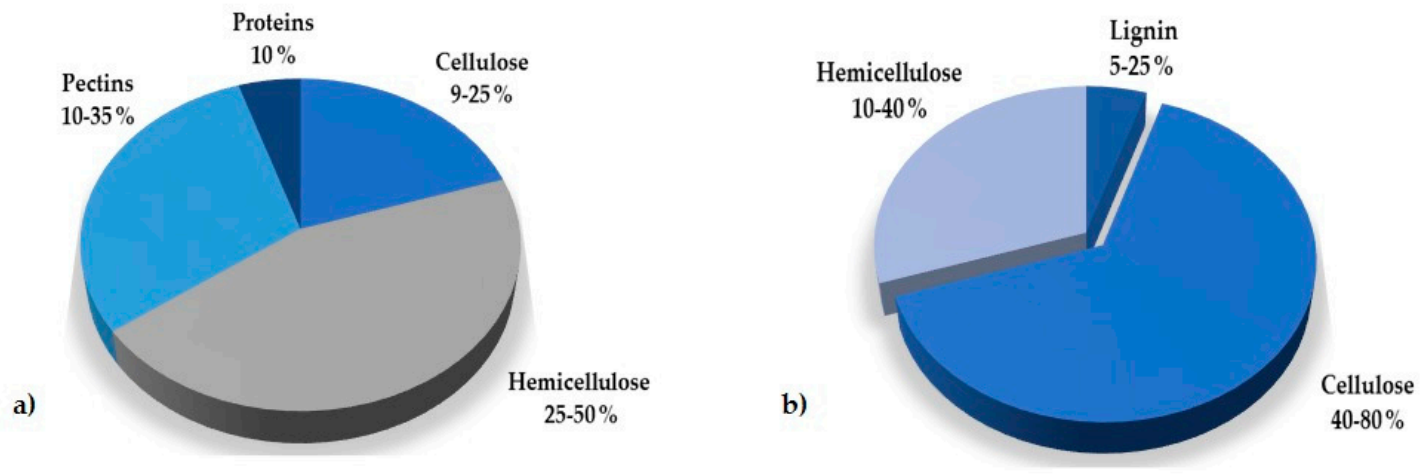

Figure 1. Composition of the cell wall in plants. (a) primary wall, (b) secondary wall.

Lignocellulosic biomass is composed of three main biopolymers: cellulose, hemicellulose and lignin [12]. The individual composition of different lignocellulosic substrates on dry basis is presented in Table 2 and the structure is presented in Figure 2. 
Table 2. Composition of different lignocellulosic substrates; cellulose, hemicellulose, and lignin content (\%) on dry basis.

\begin{tabular}{ccccc}
\hline \multirow{2}{*}{ Lignocellulosic Substrates } & \multicolumn{3}{c}{ Composition $\mathbf{( \%}$ Dry Basis) } \\
\cline { 2 - 5 } & Cellulose & Hemicellulose & Lignin & References \\
\hline Bamboo stem & 43.04 & 22.13 & 27.14 & {$[13]$} \\
Birch & $40.1 \pm 0.6$ & $17.5 \pm 0.2$ & $24.2 \pm 0.1$ & {$[14]$} \\
Corn cob & $42.0 \pm 0.1$ & $45.9 \pm 0.9$ & $2.8 \pm 0.2$ & {$[15]$} \\
Corn stalk & $36.4 \pm 0.1$ & $30.3 \pm 0.1$ & $6.9 \pm 1.4$ & {$[16]$} \\
Corn stover & 42.21 & 22.28 & 19.54 & {$[17]$} \\
Corn straw & $49.3 \pm 1.8$ & $28.8 \pm 1.4$ & $7.5 \pm 0.4$ & {$[18]$} \\
Cotton Stalk & $41.6 \pm 0.5$ & $23.6 \pm 0.4$ & $23.3 \pm 0.7$ & {$[19]$} \\
Eucalyptus & $52.07 \pm 2.6$ & $24.51 \pm 1.1$ & $25.2 \pm 1.1$ & {$[20]$} \\
Empty fruit bunch & 34.9 & 26.64 & 31.1 & {$[21]$} \\
Giant reed & $41.5 \pm 2.6$ & $20.5 \pm 0.6$ & $18.4 \pm 1.4$ & {$[22]$} \\
Grass & $47.12 \pm 3.2$ & $36.01 \pm 3.17$ & $11.55 \pm 0.3$ & {$[23]$} \\
Maize straw & $38.33 \pm 0.8$ & $29.76 \pm 1.35$ & $3 . .82 \pm 0.5$ & {$[24]$} \\
Meadow grass & $41.28 \pm 5.3$ & $28.14 \pm 3.2$ & $30.14 \pm 7.9$ & {$[25]$} \\
Miscanthus & $36.3 \pm 2.1$ & $22.16 \pm 1.9$ & $22.55 \pm 2.5$ & {$[26]$} \\
Oat straw & 35.0 & 28.2 & 4.1 & {$[27]$} \\
Pinewood & $38.5 \pm 1.9$ & $26.1 \pm 1.1$ & $11.6 \pm 1.6$ & {$[28]$} \\
Poplar & $38.2 \pm 0.3$ & $24.1 \pm 0.7$ & $34.4 \pm 0.3$ & {$[29]$} \\
Rice hulls & $46.0 \pm 0.1$ & $16.7 \pm 0.1$ & $26 . .6 \pm 0.3$ & {$[14]$} \\
Rice straw & 36.0 & 12.0 & 26.0 & {$[30]$} \\
Rye Straw & $37.8 \pm 0.2$ & $29.6 \pm 0.7$ & $14.8 \pm 0.4$ & {$[31]$} \\
Sawdust waste & $36.5 \pm 0.1$ & NR & $21.3 \pm 0.1$ & {$[32]$} \\
Sorghum straw & $31.5 \pm 1.3$ & $26.1 \pm 2.1$ & $24.9 \pm 1.7$ & {$[33]$} \\
Spruce & $26.93 \pm 1.2$ & $32.57 \pm 1.9$ & $10.16 \pm 1.8$ & {$[34]$} \\
Sugarcane bagasse & $24.7 \pm 0.2$ & $10.2 \pm 0.1$ & $35.0 \pm 0.3$ & {$[35]$} \\
Sunflower stalk & $46.1 \pm 0.7$ & $20.1 \pm 0.9$ & $20.3 \pm 0.6$ & {$[36]$} \\
Water hyacinth & $34 \pm 0.6$ & $20.8 \pm 0.8$ & $29.7 \pm 0.6$ & {$[37]$} \\
Wheat straw & $36.84 \pm 0.8$ & $27.7 \pm 0.2$ & $10.7 \pm 0.4$ & {$[38]$} \\
Willow sawdust & 43.4 & 26.9 & 22.2 & {$[39]$} \\
\hline & $35.6 \pm 0.9$ & $21.5 \pm 0.9$ & $28.7 \pm 0.2$ & {$[40]$} \\
\hline
\end{tabular}

NR: Not Reported.

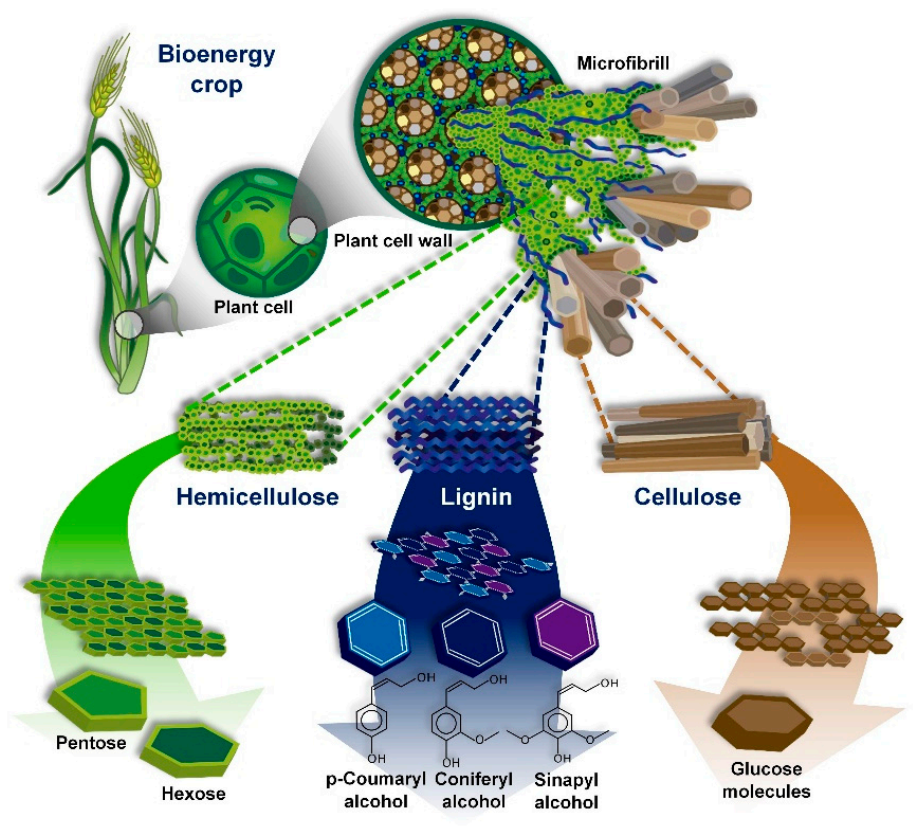

Figure 2. Structure of lignocellulosic biomass and its biopolymers; cellulose, hemicellulose, and lignin. 
Cellulose is the major component of plant cell structure and is a homo-polymer made of $\beta-1,4$-glycosidic bonds, which give stiffness and stability, characteristic to 1 structure of the cell wall [41]. The principal unit of cellulose, D-pyran glucose, makes the crystalline and amorphous regions in the cellular arrangement. The orientation and direction that have the chains of cellulose is of vital importance and determine their function. In the primary wall are the first type of alpha helical, (lower molecular weight than the secondary wall) allowing the cell storing sugars and fluids [42]. On the other hand, secondary wall cellulose chains are rigid and straight to give the molecular structure to the cell [43].

Lignin is formed from the oxidation of phydroxycinnamyl alcohols: p-coumaryl, coniferyl, and sinapyl. The formation of lignin involves three routes of biosynthesis: the shikimate pathway, the phenylpropanoid pathway and the synthesis of monolignols [46]. The units of lignin formation are: guaiacyl (G), syringyl (S), and p-hydroxyphenyl (H) [47]. The structure formed by three-dimensional and amorphous heteropolymers of lignin helps the cell in situations of stress, whether due to structural or metabolic damage, also serves as protection of the cell wall against pathogens [48].

\section{Biogas as a Sustainable Energy}

The implementation of biomass as sources of renewable energy technology is considered as sustainable technology in meeting energy needs and as well as to minimize the emission of greenhouse gases. In addition, biomass use presents the advantage of cost-benefit viability and reduce the waste flow into the environment [49].

The production of biogas from lignocellulosic substrates through the transformation of volatile organic solids (VS) by anaerobic digestion is proven to be an alternative source of energy. The potential of biogas from waste can substitute current use of natural gas in many regions [50]. Biogas is produced through a bioprocess involving four steps-i.e., hydrolysis, acidogenesis, acetogenesis, and methanogenesis-using a microbial consortium containing many different types of bacteria and archaea [51] as shown in Figure 3. Composition of biogas slightly varies depending on the type of feedstock used in anaerobic digestion. It is mainly composed by $\mathrm{CH}_{4}(40-75 \%)$ and $\mathrm{CO}_{2}(25-60 \%)$, with minor impurities such as $\mathrm{H}_{2} \mathrm{~S}, \mathrm{NH}_{3}$, among others [52]. Furthermore, $\mathrm{CO}_{2}$, the second major component can be sequestered and used to produce chemicals [53].

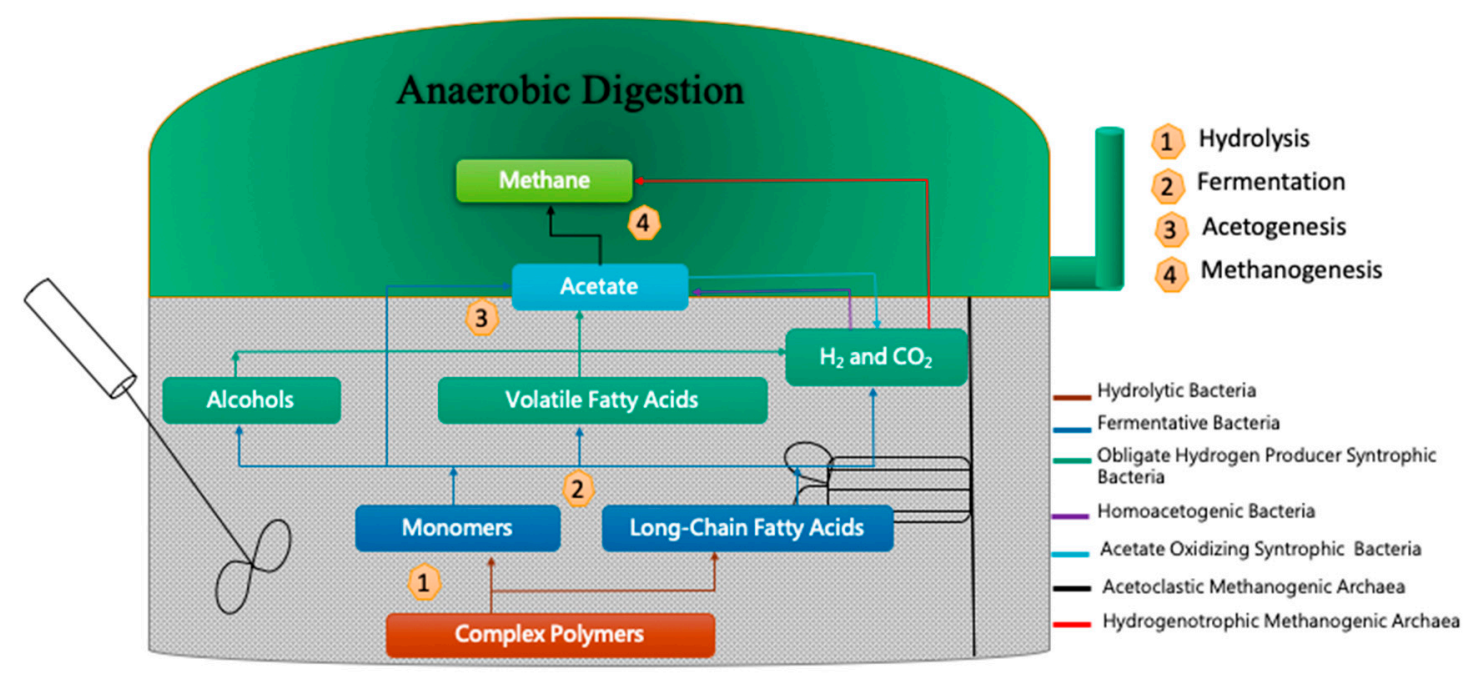

Figure 3. Steps and microorganisms involved in biogas production.

Hemicellulose can also be found in the primary cell wall in contrast to the cellulose which is present mainly within the secondary wall [44]. It is in turn the second most abundant polysaccharide compound in nature. It has as sub units D-xylose, mannose, L-arabinose, galactose, and glucuronic acid which have links " $\beta-1,4-$ glycosidic bonds in main chains; " $\beta-1.2-, " \beta-1.3-, " \beta-1.6-$ glycosidic bonds; 
with a number, less than 200 units of polymerization (polyxylose, galactoglucomannan, glucomannan). Xylan is the main polysaccharide present in hemicellulose in plants [45].

However, the heterogeneity in chemical composition of lignocellulosic biomass implies an important technological and operational challenge [54] and use of either mechanical, chemical, physiochemical, or biological pretreatments has been shown to improve their biodegradability [55].

\section{Pretreatment Methods in the Chain of Biogas Production}

Pretreatment or fractionation is an important tool to alter the structure of lignocellulosic biomass to make the holocellulose (cellulose + hemicellulose) bioavailable for bioconversion [56].

The main objective of pretreatment is the disruption of the physical barriers of the cell wall to depolymerize and to reduce the cellulose crystallinity [57]. Regardless of the type of biomass, pretreatment has been identified as the crucial step, both technically and economically, in the bioconversion of lignocellulosic biomass for its use in biorefinery [58]. The pretreatment method must have to be economical as both for operating and capital costs could be more than $40 \%$ of the total processing cost [59].

A large number of pretreatment methods for biomass have been studied, which can be broadly classified into (1) mechanical processes and this refers to reduce particle size; (2) chemical processes through the use of diluted acids, alkalis, or organic solvents; (3) physicochemical processes such as steam explosion and hot water; and (4) biological processes through the use of microbial consortia or by enzymatic means [60] as shown in Figure 4.

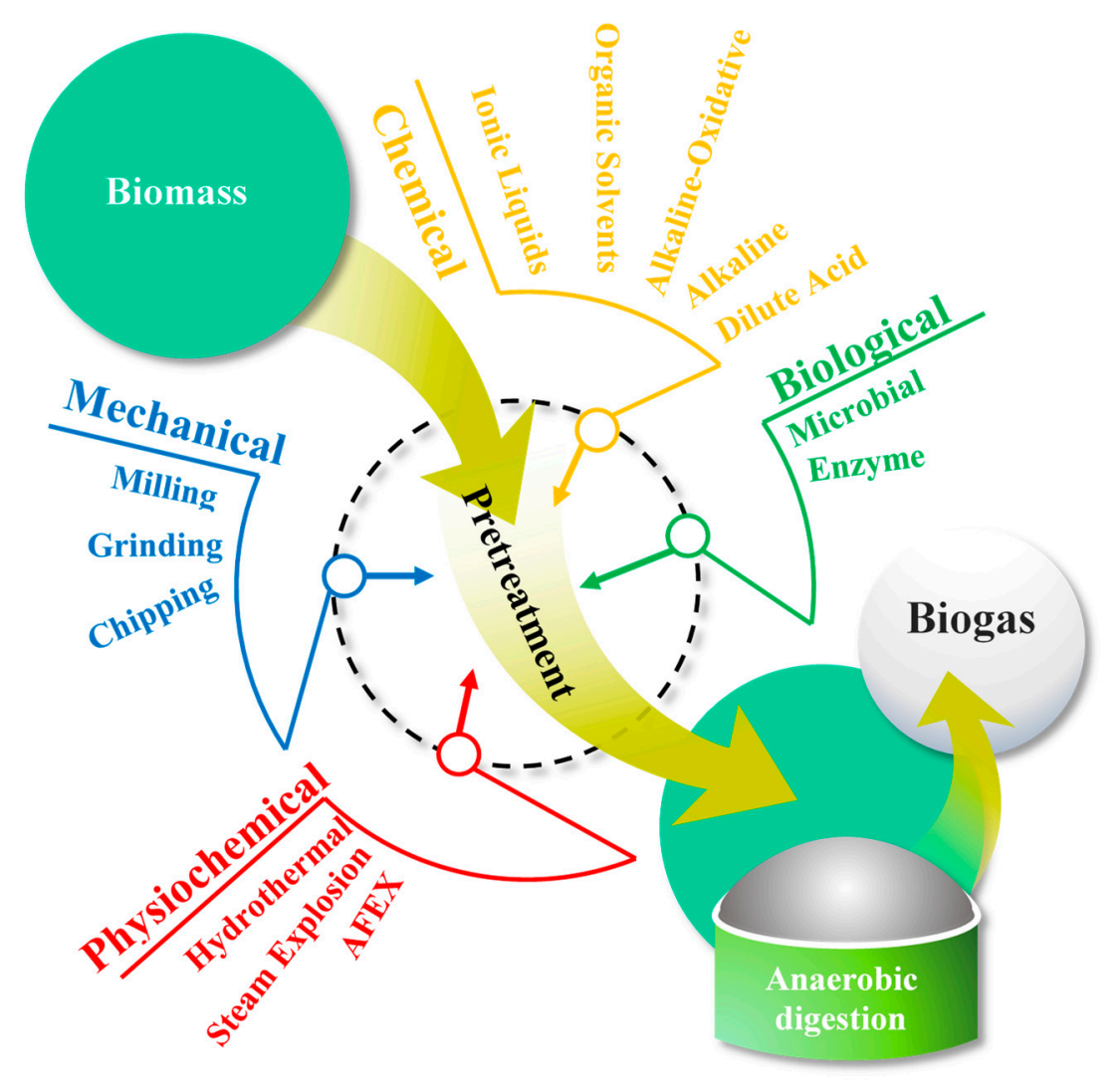

Figure 4. Pretreatment methods to increase the bioavailability of lignocellulosic biomass.

\subsection{Mechanical}

The mechanical pretreatment is the reduction of the particle size by methods such as milling, chipping, or grinding [61]. Mechanical pretreatment is well-known method to improve biogas production, however it is yet considered to be an expensive method, due its high energy 
requirements [62]. The size reduction of lignocellulosic biomass is an essential step to increase the accessible surface area and the porosity of the particles, besides reducing the crystallinity of the cellulose and improves the efficiency of the next processing step and global production chain [63]. One advantage of mechanical pretreatment is that it does not produce any secondary inhibitory substances, which suggest that could be suitable for methane production or any other bioprocess [64]. Dahunsi [64] reported that mechanical pretreatment applied to six different lignocelluloses caused breakdown of structural material and increased the methane yield up to $22 \%$. However, it is observed that excessive size reduction of lignocellulosic biomass can lead to a lower efficiency of methane production [61]. Process efficiency in terms of cost-energy, operational aspects such as the right particle size, processing time of mechanical pretreatment, and the mechanical speed for size reduction must be standardized. It can be observed from literature that there is no universal particle size suitable for biomethanation process and it varies according to the type of the substrate and the process used for biomethanation. Dumas et al. [65] found negligible differences in biogas yield of wheat straw having the particle size in the range from 0.7 to $0.2 \mathrm{~mm}$, and that the methane yield did not show any increase at particle size of $0.048 \mathrm{~mm}$. Sharma et al. [66] compared the effect of different particle size, viz., 0.088 , $0.40,1.0$, and $6.0 \mathrm{~mm}$ of various agricultural residues—such as wheat straw, rice straw, Mirabilis leaves, cauliflower leaves, Ipomoea fistulosa leaves, dhub grass, and banana peel—and observed that the highest biogas yield was observed with residues having a particle size $0.88 \mathrm{~mm}$. They further reported that there was no statistical difference in biogas yield between 0.4 and $0.088 \mathrm{~mm}$. However, De la Rubia et al. [67] observed the highest methane yield in sunflower oil cake at particle size $1.4-2.0 \mathrm{~mm}$, which was $17 \%$ higher than the particle size in the range of $0.355-0.55 \mathrm{~mm}$. Chandra et al. [68] also observed the particle size of $0.30 \mathrm{~mm}$ of wheat and rice straw did not show any significant increase in methane yield in comparison to the particle size $0.75 \mathrm{~mm}$ of both straws. However, both particle sizes showed an increase than the untreated particle size of $1.5 \mathrm{~mm}$.

Tsapekos et al. [69] tested six different mechanical pretreatments, which generated particle size in the range of 0 to $>20 \mathrm{~cm}$. They reported that the mechanical pretreatments which generated particle size larger than $>20 \mathrm{~cm}$, equivalent to $33 \%$ and $41 \%$ of the total of biomass did not show any significant increase in yield than untreated biomass. The methane yield was significant higher and improved by $25 \%$ where the amount of biomass with particle size greater than $>20 \mathrm{~cm}$ was the about only $22 \%$ of the total of biomass. Similarly, Herrmann et al. [70] found a close correlation between particle length and methane yield while comparing different particle length of the same crop material. Krause et al. [71] studied two different particle sizes, $<2 \mathrm{~mm}$ and $>20-100 \mathrm{~mm}$, in different substrates like softwood, hardwood, and cotton and found that increase in methane yield was positively correlated with reduced particle size.

On the other side, the processing time on particle reduction is not only important in energy terms, but also influence the efficiency of the bioconversion of lignocellulosic biomass [59]. Rodríguez et al. [63] compared 30 and 60 min of mechanical pretreatment, and reported a $21 \%$ increase in methane yield for $60 \mathrm{~min}$ and that $30 \mathrm{~min}$ pretreatment did not improve the methane yield. For the cost reduction of the energy involved in mechanical pretreatments, the speed of the milling equipment must be considered [72]. Tsapekos et al. [25] evaluated different speeds of milling, in the range of 200 to 1200 rpm on methane yield from meadow grass and observed that there was no difference due to the milling speeds tested. They observed $27 \%$ increase in methane yield in treatments than the untreated biomass.

The methane yield from different mechanically pretreated lignocellulosic substrates is presented in Table 3. It can be observed that different particle sizes were found to be optimum for different types of lignocellulosic biomass. In the case of wheat straw, particle size of $2 \mathrm{~mm}$ increased the methane yield to an order of $83 \%$ [73]. Likewise, barley straw presented an increase of $54 \%$ and $41 \%$ of methane yield at particle size of $5 \mathrm{~mm}$ and $20 \mathrm{~mm}$, respectively [73]. It can also be observed that particle sizes larger and smaller than the range between 2 and $5 \mathrm{~mm}$, presented a decrease in methane yield [68,73,74]. The observed variations on the effect of particle size, time, and speed of milling pointed out that apparently the best strategy for the mechanical pretreatment depends on the type the lignocellulosic material and a universal strategy cannot be recommended. 
Table 3. Effect of mechanical pretreatments on methane yield from lignocellulosic biomass.

\begin{tabular}{|c|c|c|c|c|c|}
\hline Substrates & Particle Size & $\begin{array}{l}\text { Methane Yield } \\
\text { (Untreated) }\end{array}$ & $\begin{array}{l}\text { Methane Yield } \\
\text { (After Treatment) }\end{array}$ & Reaction System & References \\
\hline \multirow{3}{*}{ Barley Straw } & $5 \mathrm{~mm}$ & $240 \mathrm{~mL} / \mathrm{g}$ VS & $370 \mathrm{~mL} / \mathrm{g}$ VS & Glass reactor $2 \mathrm{~L}$ & [73] \\
\hline & $20 \mathrm{~mm}$ & $240 \mathrm{~mL} / \mathrm{g}$ VS & 339 mL/g VS & Glass reactor $2 \mathrm{~L}$ & [73] \\
\hline & $50 \mathrm{~mm}$ & $240 \mathrm{~mL} / \mathrm{g}$ VS & $286 \mathrm{~mL} / \mathrm{g} \mathrm{VS}$ & Glass reactor $2 \mathrm{~L}$ & [73] \\
\hline $\begin{array}{l}\text { Crop feedstocks (winter } \\
\text { rye, sorghum, forage rye, } \\
\text { maize, triticale) }\end{array}$ & $6-33 \mathrm{~mm}$ & $278 \mathrm{~mL} / \mathrm{g}$ ODM & $403 \mathrm{~mL} / \mathrm{g}$ ODM & $\begin{array}{l}\text { Stirred tank } \\
\text { reactor } 3 \mathrm{~L}\end{array}$ & [70] \\
\hline \multirow[b]{2}{*}{ Maize stalks } & $2 \mathrm{~mm}$ & $246 \mathrm{~mL} / \mathrm{g}$ VS & $272 \mathrm{~mL} / \mathrm{g}$ VS & Glass reactor $2 \mathrm{~L}$ & [73] \\
\hline & $20 \mathrm{~mm}$ & $246 \mathrm{~mL} / \mathrm{g}$ VS & $254 \mathrm{~mL} / \mathrm{g}$ VS & Glass reactor $2 \mathrm{~L}$ & [73] \\
\hline \multirow{3}{*}{ Meadow grass } & $2 \mathrm{~mm}$ & $297 \mathrm{~mL} / \mathrm{g}$ VS & $376 \mathrm{~mL} / \mathrm{g}$ VS & Bottle $0.5 \mathrm{~L}$ & [25] \\
\hline & $<200 \mathrm{~mm}$ & - & $\begin{array}{c}347 \mathrm{~mL} / \mathrm{g} \mathrm{VS} \\
\text { (increase 20\%) }\end{array}$ & Bottle $0.5 \mathrm{~L}$ & [72] \\
\hline & $0-200 \mathrm{~mm}$ & $303 \mathrm{~mL} / \mathrm{g}$ VS & $372 \mathrm{~mL} / \mathrm{g}$ VS & Bottle $0.5 \mathrm{~L}$ & [69] \\
\hline \multirow{3}{*}{ Rice straw } & $0.3 \mathrm{~mm}$ & $58.1 \mathrm{~mL} / \mathrm{g}$ VS & $62.7 \mathrm{~mL} / \mathrm{g} \mathrm{VS}$ & - & [68] \\
\hline & $0.75 \mathrm{~mm}$ & $58.1 \mathrm{~mL} / \mathrm{g}$ VS & $65.7 \mathrm{~mL} / \mathrm{g} \mathrm{VS}$ & - & [68] \\
\hline & $50 \mathrm{~mm}$ & 197 mL/g VS & 203 mL/g VS & Glass reactor $2 \mathrm{~L}$ & [73] \\
\hline Switchgrass & $2-10 \mathrm{~mm}$ & $127.4 \mathrm{~mL} / \mathrm{g} \mathrm{VS}$ & $170.7 \mathrm{~mL} / \mathrm{g} \mathrm{VS}$ & Bottle $0.5 \mathrm{~L}$ & [75] \\
\hline \multirow{4}{*}{ Water hyacinth } & $0.001 \mathrm{~mm}$ & - & $\begin{array}{c}\text { Increase } 20 \% \\
\text { (from } 50 \text { to } 70 \% \text { ) }\end{array}$ & Digester $0.45 \mathrm{~L}$ & [76] \\
\hline & $0.05 \mathrm{~mm}$ & - & $\begin{array}{c}\text { Increase } 16 \% \\
\text { (from } 50 \text { to } 66 \% \text { ) }\end{array}$ & Digester $0.45 \mathrm{~L}$ & [76] \\
\hline & $1.0 \mathrm{~mm}$ & - & $\begin{array}{c}\text { Increase } 10 \% \\
\text { (from } 50 \text { to } 60 \% \text { ) }\end{array}$ & Digester $0.45 \mathrm{~L}$ & [76] \\
\hline & $2.5 \mathrm{~mm}$ & - & $\begin{array}{c}\text { Increase } 5 \% \\
\text { (from } 50 \text { to } 55 \% \text { ) }\end{array}$ & Digester $0.45 \mathrm{~L}$ & [76] \\
\hline \multirow{7}{*}{ Wheat straw } & $0.3 \mathrm{~mm}$ & $167.8 \mathrm{~mL} / \mathrm{g}$ VS & $245.6 \mathrm{~mL} / \mathrm{g} \mathrm{VS}$ & Reactor $2 \mathrm{~L}$ & [74] \\
\hline & $1.2 \mathrm{~mm}$ & $167.8 \mathrm{~mL} / \mathrm{g} \mathrm{VS}$ & $264.7 \mathrm{~mL} / \mathrm{g} \mathrm{VS}$ & Reactor $2 \mathrm{~L}$ & [74] \\
\hline & $0.3 \mathrm{~mm}$ & 67.1 mL/g VS & $70.3 \mathrm{~mL} / \mathrm{g} \mathrm{VS}$ & - & [68] \\
\hline & $0.75 \mathrm{~mm}$ & $67.1 \mathrm{~mL} / \mathrm{g} \mathrm{VS}$ & $93.1 \mathrm{~mL} / \mathrm{g} \mathrm{VS}$ & - & [68] \\
\hline & $0.088-0.759 \mathrm{~mm}$ & $183.4 \mathrm{~mL} / \mathrm{g} \mathrm{VS}$ & $252.8 \mathrm{~mL} / \mathrm{g}$ VS & Lab Flask & [65] \\
\hline & $2 \mathrm{~mm}$ & 182 mL/g VS & 334 mL/g VS & Glass reactor $2 \mathrm{~L}$ & [73] \\
\hline & $50 \mathrm{~mm}$ & $182 \mathrm{~mL} / \mathrm{g}$ VS & $285 \mathrm{~mL} / \mathrm{g} \mathrm{VS}$ & Glass reactor $2 \mathrm{~L}$ & [73] \\
\hline Waste paper & $\begin{array}{l}60 \mathrm{~min} \text { of } \\
\text { beating time }\end{array}$ & $132 \mathrm{~mL} / \mathrm{g}$ VS & 215 mL/g VS & Flask $0.5 \mathrm{~L}$ & [63] \\
\hline
\end{tabular}

\subsection{Chemical Pretreatments}

Chemical pretreatment of lignocellulosic biomass with acids, alkalis, and organic solvents [77] are considered as one of the most promising, since they can be quite effective in degrading more complex-structured substrates [78]; further improves the bioavailability of carbohydrates by removing lignin and/or by decreasing the degree of polymerization and cellulose crystallinity [79]. Chemical pretreatment has gained larger attention because they usually less expensive and result in faster rates and better efficiencies in enhancing the degradation complex organic molecules.

\subsubsection{Acid}

The main objective of dilute acid treatment is to achieve greater access to carbohydrate fractions of cellulose by hydrolyzing the hemicellulose [80]. Low acid concentration at $0.2 \%$ to $2.5 \% v / v$ and temperatures between $130{ }^{\circ} \mathrm{C}$ and $210^{\circ} \mathrm{C}$ are employed [81], a common practice is the use of autoclave at $121^{\circ} \mathrm{C}$ for $1 \mathrm{~h}[82,83]$. On the contrary, low temperature (room temperature) is used while using high reagent acid concentration (above 30\% v/v). High acid concentrations could cause corrosion problems and as a result high maintenance costs [84] and further, generate inhibitor compounds at high rate and therefore increase the purification costs. Many studies confirmed that the dilute acid treatment is the most promising technology for lignocellulose pretreatment [85]. According to Syaichurrozi et al. [86], pretreatment of Salvinia molesta pretreatment by $2 \%, 4 \%$, and $6 \% v / v$ of sulfuric acid $\left(\mathrm{H}_{2} \mathrm{SO}_{4}\right)$ 
increased methane yield around $100 \%$ in comparison to untreated, however no yield differences were reported between the tested concentrations. Similarly, Song et al. [18] observed that $2 \%$ sulfuric acid pretreatment of corn straw resulted in the highest methane concentration of $175 \mathrm{~mL} / \mathrm{g}$ VS. Further, they reported that use of $2 \%$ hydrochloric acid and $4 \%$ acetic acid yielded lower methane production than sulfuric acid, of 163 and $145 \mathrm{~mL} / \mathrm{g}$ VS respectively. Germec et al. [87] found that the optimum acid concentration for pretreatment of spent tea leaves was $1.58 \% v / v$. In relation to the temperature and reaction time, Germec et al. [87] observed that $131^{\circ} \mathrm{C}$ for $20 \mathrm{~min}$ was efficient than $121^{\circ} \mathrm{C}$ for $1 \mathrm{~h}$, which was also suggested by Saha and Cotta [83]. On the other hand, Syaichurrozi et al. [86] recommended the dilute acid pretreatment at room temperature of $30^{\circ} \mathrm{C}$ for 2 days.

\subsubsection{Alkaline}

Alkaline pretreatment shows high efficiency [88], especially in the delignification process [89]. Alkaline pretreatment produces a swelling reaction in the cell wall allowing an increase in the internal surface area, and simultaneously decrease of polymerization degree and crystallinity of cellulose [84]. To take full advantage of these alkaline effects, critical process parameter such as alkaline loading, reaction temperature, and quantity must be optimized [90].

High concentrations of alkaline reagent lead to degradation and decomposition of polysaccharides. Low concentrations at low temperature and at atmospheric pressure are recommended [30]. Furthermore, it does not generate toxic compounds such as furfurals and hydroxymethylfurfurals (HMF), and hence higher efficiency is observed in the biomethanation process.

Although, there is still discrepancy on the choice of alkaline reagent, in terms of the greatest advantages, considering the cost of the reagent, performance, and manipulation [91], sodium hydroxide is preferred because it catalyzes under mild conditions, effectively attacks the linkage between lignin and hemicellulose in lignin-carbohydrate; in particular it cleaves the ether and ester bonds in the lignocellulose structure and also effective in the cleavage of the ester and carbon-to-carbon bonds in lignin molecules [92-94]. Jiang et al. [22] and Xihui et al. [95] optimized the $\mathrm{NaOH}$ loading rate to increase the methane yield. Jiang et al. [22] varied the $\mathrm{NaOH}$ concentration between $0.5 \%$ and $2 \%$ $\mathrm{w} / \mathrm{v}$ for pretreatment of giant reed, and observed an increase in methane yield from $217 \mathrm{~mL} / \mathrm{g} \mathrm{VS}$ to $355 \mathrm{~mL} / \mathrm{g}$ VS after pretreating at $\% \mathrm{w} / \mathrm{v}$. Likewise, Xihui et al. [95] achieved the highest methane yield of $201 \mathrm{~mL} / \mathrm{g}$ VS from Pennisetum hybrid at $\% \mathrm{w} / \mathrm{w}$ of NaOH, and they tested the alkali pretreatment at concentrations of $2 \%, 4 \%, 6 \%$, and $8 \% \mathrm{w} / \mathrm{w}$.

However, sodium discharge might be environmentally harmful as they can lead to negative impacts such as soil salinization. $\mathrm{KOH}$, although is three times more expensive than $\mathrm{NaOH}$, it represents is an alternative solution. Romero-Güiza et al. [96] reported an increase of $128 \%$ methane yield from $0.7 \% \mathrm{w} / \mathrm{w} \mathrm{KOH}$ pretreated wheat straw than the untreated wheat straw. Moset et al. [97] compared $\mathrm{NaOH}$ and $\mathrm{KOH}$ pretreatment $(0.5$ to $8 \%$ ) of wheat straw on biogas yield and reported the highest methane yield of $374 \mathrm{~mL} / \mathrm{g}$ VS and $370 \mathrm{~mL} / \mathrm{g}$ VS with $2 \% \mathrm{NaOH}$ and $0.5 \% \mathrm{KOH}$ respectively, and untreated straw recorded a methane yield of $303 \mathrm{~mL} / \mathrm{g}$ VS. These results indicated that requirement of lower concentration of $\mathrm{KOH}$ could offset its high cost. In addition, $\mathrm{KOH}$ is easily recovered, and its discharge might have a potential soil amendment value since potassium is a nutrient required for plant growth [96]. Thomas et al. [26] suggested the alternative option of using $\mathrm{CaO}$. However, they observed that $\mathrm{NaOH}$ was more efficient than $\mathrm{CaO}$ and increased the methane production in the range of 24 and $55 \%$ from the pretreated Miscanthus $x$ giganteus, M. sacchariflorus, and M. sinensis, while the increase was between 19 and $30 \%$ for Cao treated samples. However, $\mathrm{CaO}$ is an interesting alternative alkali reagent as it is already used to mitigate soil acidity and is also less expensive than $\mathrm{NaOH}$.

Calcium hydroxide is another common alkali reagent used, Gu et al. [98] tested five different concentrations of $\mathrm{Ca}(\mathrm{OH})_{2}: 6 \%, 8 \%, 10 \%, 12 \%$, and $15 \%$, in which the highest biogas production from obtained at $8 \%$ and $10 \%$ pretreated rice straw and recorded a biogas production of $564.7 \mathrm{~mL} / \mathrm{g} \mathrm{VS}$ and $574.5 \mathrm{~mL} / \mathrm{g}$ VS, respectively, which is $34.3 \%$ and $36.7 \%$ higher than untreated biomass. 


\subsubsection{Organosolv}

Organosolv pretreatment emerges as the only technology capable of isolating each component of the lignocellulosic biomass, attaining relatively pure lignin that can be sold as a by-product or converted into higher-value products in a biorefinery concept [99]. Organic solvents-such as methanol, ethanol, acetone, acetic acid, peracetic acid, and so on-are used with or without the addition of a catalyst reagent [100]. The catalysts used include mineral acids (hydrochloric, sulfuric, and phosphoric acids) and organic acids (oxalic, acetylsalicylic, and salicylic acids) [101]. Although catalyst addition aids in higher pretreatment efficiency, use of a catalyst could have a negative impact on the environment [102], i.e., chemical catalyst as acid causes acid-catalyzed degradation of the monosaccharides into furfural and 5-hydroxymethyl furfural followed by condensation reactions between lignin and the reactive aldehydes [103]. Acid catalysts are added in order to increase the rate of lignin removal and decrease pretreatment temperature, because acid catalysts cleave acid-labile bonds ( $\alpha$-aryl ether and arylglycerol- $\beta$-aryl ether bonds), which help stabilization of lignin fragments [101]. However, the use of chemical catalysts involves issues, such as equipment corrosion and the need of processing downstream effluents, resulting in high water consumption [103]. Formic acid is a promising catalyst as it is believed to have fewer corrosive effects than stronger mineral acids and further to avoid production of inhibitors that are normally formed when acetic acid is employed [104].

The organosolv process causes hydrolysis of the internal bonds in lignin and between lignin and hemicellulose. The organic solvents also cause hydrolysis of the glyosidic bonds in hemicelluloses and to a smaller extent in cellulose [103]. The preferred conditions of organosolv process is generally in the following ranges: a cooking temperature of $180-195{ }^{\circ} \mathrm{C}$, a cooking time of $30-90 \mathrm{~min}$ and liquor to solid ratio ranging from 4:1 to 10:1 [105].

As mentioned previously, organic acids have been suggested as an alternative to inorganic ones, to avoid corrosion and decrease the energy demand during acid recovery. Amnuaycheewa et al. [106] pretreated the rice straw with organic acids—such as acetic acid, citric acid, and oxalic acid—and make a comparison with hydrochloric acid as inorganic acid. It was found that pretreatment with oxalic acid reagent yielded 2.68 and 1.25 times higher reducing sugars than untreated and $\mathrm{HCl}$-treated rice straw, respectively. Further, the accumulated methane yields obtained from pretreatments of organic acids were 2.47-2.53 times higher than the inorganic acid one.

A critical issue with organosolv pretreatment is the risk of operating at high pressure and the solvents volatility due to their low boiling point of the organic solvents. A system of solvent recovery is necessary to reduce the cost of operation and to avoid their residual inhibitory effect on microorganisms. Teghammar et al. [107] recovered more than $98 \%$ of organic solvent N-methylmorpholine-N-oxide (NMMO or NMO), which was used for pretreatment of softwood spruce, rice straw, and triticale straw at $130{ }^{\circ} \mathrm{C}$ for $1-15 \mathrm{~h}$. Further, they reported an increase in methane production between $400 \%$ and $1200 \%$. Kabir et al. [108] studied the use of recycled NMMO for pretreatment of barley straw and forest residues and observed similar performance as the fresh NMMO on barley straw. However, pretreatment of forest residues with recycled NMMO resulted in 55\% reduction of methane yield.

Among solvents, low boiling point alcohols, especially ethanol, have attracted more attention because of their high effectiveness on lignocellulosic biomass, as well as the simplicity of their recovery by distillation [109]. Other advantages are lower cost and lower toxicity to humans compared to solvents as methanol [104,110].

\subsubsection{Ionic Liquids}

Ionic liquids are environmental friendly and represent a new class of solvents which have high polarities, a low melting point, non-volatility, and design-ability [111]. Ionic liquid-based pretreatment gained attention due to their effectiveness on a range of biomass types, even in the scale-up from lab scale to small pilot scale, and their ability to disrupt lignin and decrystallize cellulose [112].

Ionic liquids have unique properties compared to traditional solvents, including a low vapor pressure, which avoids atmospheric emissions by eliminating solvent losses through evaporation. 
They also have a relatively high thermal stability, low flammability, and possibility of recycling, which contributes to the reduction of waste [111].

Ionic liquids can be easily prepared using different cations and anions, resulting in hydrophobic or hydrophilic types, according to the desired application [113]. Cations of methylimidazolium and methylpyridinium with allyl-, ethyl-, or butyl-chains are commonly used. Meanwhile, the most effective anions are halogens, formates, acetates, amides, imides, thiocynates, phosphates, sulfites, sulfonates, and dichloroaluminates [114]. Kim et al. [115] studied the transition of the crystalline structure when lignocelluloses such as cotton stalks, hemp stalks, and acacia pruning were pretreated with 1-ethyl-3-methylimidazolium acetate (EmimOAC) or 1-ethyl-3-methylmidazolium chloride $(\mathrm{EmimCl})$, and the results indicated that type of anion in the ionic liquid significantly influenced the efficiency of lignin and hemicellulose removal. Acetate anion showed greater cellulose extraction from lignocellulose substrates.

There are various parameters affecting the process of biomass pretreatment using ionic liquids: for instance, physiochemical properties of ionic liquid, reaction time and temperature, ratio of biomass to ionic liquid, biomass type, and water content of sample. Physiochemical property like viscosity is probably the most negative parameter of the process because extremely viscous solution is formed during pretreatment and significantly affect the industrial application of ionic liquids [116].

A disadvantage of ionic liquids is their high cost, therefore, a strategy to follow is the recycling to compensate their high production costs [117]. To make ionic liquid pretreatment economically feasible, [118] a recovery of $>97 \%$ of ionic liquid used and $>90 \%$ waste heat recovery is recommended. $\mathrm{Xu}$ et al. [20] evaluated the efficiency of reuse of ionic liquids 1-allyl-3-methylimidazolium chloride (amimCl) and 1-butyl-3-methylimidazolium acetate (bmimOAc) on eucalyptus and reported that four reusing cycles were effective, where hydrolysis efficiencies of $54.3 \%$ for $(\mathrm{amimCl}$ ) and $72.8 \%$ for (bmimOAc) were observed. After their fourth reuse, ionic liquids showed deteriorations by relatively lower sugar conversion and lignin removal. Gao et al. [35] evaluated the water hyacinth pretreated with 1-N-butyl-3-methyimidazolium chloride [BmimCl]/dimethyl sulfoxide (DMSO) at $120{ }^{\circ} \mathrm{C}$ for $120 \mathrm{~min}$ and reported an increase in methane yield by $97.6 \%$ compared with non-pretreated water hyacinth. The ionic liquids and co-solvents were successfully recovered.

On the other hand, Xie et al. [119] simulated a process for biogas upgrading using three imidazolium-based ionic liquids 1-hexyl-3-methylimidazolium bis(trifluoromethylsulfonyl)imide [hmim][Tf2N], 1-Butyl-3-methylimidazolium bis(trifluoromethanesulfonyl)imide [bmim][Tf2N] and 1-Butyl-3-methylimidazolium hexafluorophosphate [bmim][PF6] and reported a $11 \%$ reduction in energy consumption in [bmim][Tf2N], which suggest the promising potential of ionic liquid technology for biogas upgrading.

\subsubsection{Alkaline Hydrogen Peroxide}

The alkaline reagent can be combined with hydrogen peroxide. The use of $\mathrm{H}_{2} \mathrm{O}_{2}$ improves the enzymatic digestibility in a wide range of lignocellulosic biomass with the main intention of improving the enzymatic hydrolysis yields [120]. $\mathrm{H}_{2} \mathrm{O}_{2}$ is used as a bleaching agent of lignocellulosic biomass. During the pretreatment, many free radicals are released but has the advantage of not leaving residues in the biomass because it degrades into oxygen and water and hardly forms secondary products. Thus, an oxidative fragmentation occurs, as well as lignin removal from the lignocellulosic matrix by attacking lignin side chains [121]. Alkaline hydrogen peroxide improves the performance in terms of delignification and enzymatic digestibility than single alkali reagent [122]. However, this method is limited due to the need to maintain constant $\mathrm{pH}$ during the process to avoid hemicellulose elimination, and is one of the most important parameter to achieve process efficiency [117].

Alkaline hydrogen peroxide is a delignification process, but not only improves the depolymerization of lignin, but also has the advantage of requiring mild conditions of temperature and pressure [123], which reduces the formation of inhibitors [124]. Ayeni et al. [125] studied the operating conditions of alkaline hydrogen peroxide pretreatment of sugarcane bagasse and reported optimum 
pretreatment conditions were $0.3 \%$ hydrogen peroxide concentration, $100{ }^{\circ} \mathrm{C}$ for $4.6 \mathrm{~h}$. Siciliano et al. [126] confirmed the use of low concentration of oxidant at room temperature significantly improved the anaerobic treatability of olive mill residues and reported methane yield up to $0.328 \mathrm{~L} / \mathrm{g}$ of COD (chemical oxygen demand) removed. Similarly, Katukuri et al. [127] reported $49 \%$ increase in methane yield over untreated substrate of Miscanthus floridulus by using $0.8 \%$ of $\mathrm{H}_{2} \mathrm{O}_{2}$.

On the other hand, Alencar et al. [128] evaluated the $\mathrm{H}_{2} \mathrm{O}_{2}$ recycling strategy and tested the efficiency of recycled $\mathrm{H}_{2} \mathrm{O}_{2}$ in five successive reuse cycles and reported a decrease in efficiency at each cycle of reuse than the previous.

Methane yield from different residues after pretreatment by acid, alkali, organosolv, and $\mathrm{H}_{2} \mathrm{O}_{2}$ treatment is presented in Table 4.

Table 4. Effect of different chemical pretreatments on methane yield from different lignocellulosic biomass.

\begin{tabular}{|c|c|c|c|c|c|}
\hline Subastrates & Pretreatment Conditions & $\begin{array}{l}\text { Methane Yield } \\
\text { (Untreated) }\end{array}$ & $\begin{array}{l}\text { Methane Yield (After } \\
\text { Pretreament) }\end{array}$ & $\begin{array}{l}\text { Reaction } \\
\text { System }\end{array}$ & References \\
\hline \multirow{7}{*}{ Corn Straw } & Sulfuric acid $2 \% v / v$ & $100.6 \mathrm{~mL} / \mathrm{g} \mathrm{VS}$ & $175.6 \mathrm{~mL} / \mathrm{g} \mathrm{VS}$ & Flask $1 \mathrm{~L}$ & [18] \\
\hline & Hydrochloric acid $2 \% v / v$ & $100.6 \mathrm{~mL} / \mathrm{g} \mathrm{VS}$ & $163.4 \mathrm{~mL} / \mathrm{g} \mathrm{VS}$ & Flask $1 \mathrm{~L}$ & [18] \\
\hline & Acetic acid $4 \% v / v$ & $100.6 \mathrm{~mL} / \mathrm{g} \mathrm{VS}$ & $145.1 \mathrm{~mL} / \mathrm{g} \mathrm{VS}$ & Flask $1 \mathrm{~L}$ & [18] \\
\hline & Hydrogen peroxide $3 \% v / v$ & $100.6 \mathrm{~mL} / \mathrm{g} \mathrm{VS}$ & $216.7 \mathrm{~mL} / \mathrm{g}$ VS & Flask $1 \mathrm{~L}$ & [18] \\
\hline & Sodium hydroxide $8 \% v / v$ & $100.6 \mathrm{~mL} / \mathrm{g} \mathrm{VS}$ & $163.5 \mathrm{~mL} / \mathrm{g} \mathrm{VS}$ & Flask $1 \mathrm{~L}$ & [18] \\
\hline & Calcium hydroxyde $8 \% v / v$ & $100.6 \mathrm{~mL} / \mathrm{g} \mathrm{VS}$ & $206.6 \mathrm{~mL} / \mathrm{g} \mathrm{VS}$ & Flask $1 \mathrm{~L}$ & [18] \\
\hline & Ammonia $10 \% v / v$ & $100.6 \mathrm{~mL} / \mathrm{g} \mathrm{VS}$ & $168.3 \mathrm{~mL} / \mathrm{g} \mathrm{VS}$ & Flask $1 \mathrm{~L}$ & [18] \\
\hline \multirow{3}{*}{$\begin{array}{l}\text { Cotton gin } \\
\text { waste }\end{array}$} & Citric acid $0.5 \mathrm{mmol} / \mathrm{g}$ VS substrate & $95.4 \mathrm{~mL} / \mathrm{g} \mathrm{VS}$ & $147.1 \mathrm{~mL} / \mathrm{g}$ VS & $\begin{array}{l}\text { Flask } \\
0.25 \mathrm{~L}\end{array}$ & [78] \\
\hline & Hydrogen peroxide $0.5 \mathrm{mmol} / \mathrm{g}$ VS substrate & $178.0 \mathrm{~mL} / \mathrm{g} \mathrm{VS}$ & $247.5 \mathrm{~mL} / \mathrm{g}$ VS & $\begin{array}{l}\text { Flask } \\
0.25 \mathrm{~L}\end{array}$ & [78] \\
\hline & Ethanol $0.5 \mathrm{mmol} / \mathrm{g}$ VS substrate & $172.5 \mathrm{~mL} / \mathrm{g} \mathrm{VS}$ & $241.5 \mathrm{~mL} / \mathrm{g}$ VS & $\begin{array}{l}\text { Flask } \\
0.25 \mathrm{~L}\end{array}$ & [78] \\
\hline \multirow{3}{*}{$\begin{array}{l}\text { Juice industry } \\
\text { waste }\end{array}$} & Citric acid $0.5 \mathrm{mmol} / \mathrm{g}$ VS substrate & $180.4 \mathrm{~mL} / \mathrm{g}$ VS & $353.5 \mathrm{~mL} / \mathrm{g}$ VS & $\begin{array}{l}\text { Flask } \\
0.25 \mathrm{~L}\end{array}$ & [78] \\
\hline & Hydrogen peroxide $0.5 \mathrm{mmol} / \mathrm{g}$ VS substrate & $275.0 \mathrm{~mL} / \mathrm{g} \mathrm{VS}$ & $385.6 \mathrm{~mL} / \mathrm{g} \mathrm{VS}$ & $\begin{array}{l}\text { Flask } \\
0.25 \mathrm{~L}\end{array}$ & [78] \\
\hline & Ethanol $0.5 \mathrm{mmol} / \mathrm{g}$ VS substrate & $214.3 \mathrm{~mL} / \mathrm{g} \mathrm{VS}$ & $332.8 \mathrm{~mL} / \mathrm{g} \mathrm{VS}$ & $\begin{array}{l}\text { Flask } \\
0.25 \mathrm{~L}\end{array}$ & [78] \\
\hline \multirow{3}{*}{ Olive pomace } & Citric acid $0.5 \mathrm{mmol} / \mathrm{g}$ VS substrate & $200.1 \mathrm{~mL} / \mathrm{g}$ VS & $183.2 \mathrm{~mL} / \mathrm{g}$ VS & $\begin{array}{l}\text { Flask } \\
0.25 \mathrm{~L}\end{array}$ & [78] \\
\hline & Hydrogen peroxide $0.5 \mathrm{mmol} / \mathrm{g}$ VS substrate & $178.7 \mathrm{~mL} / \mathrm{g} \mathrm{VS}$ & $172.3 \mathrm{~mL} / \mathrm{g} \mathrm{VS}$ & $\begin{array}{l}\text { Flask } \\
0.25 \mathrm{~L}\end{array}$ & [78] \\
\hline & Ethanol $0.5 \mathrm{mmol} / \mathrm{g}$ VS substrate & $193.0 \mathrm{~mL} / \mathrm{g} \mathrm{VS}$ & $157.5 \mathrm{~mL} / \mathrm{g}$ VS & $\begin{array}{l}\text { Flask } \\
0.25 \mathrm{~L}\end{array}$ & [78] \\
\hline \multirow{3}{*}{$\begin{array}{l}\text { Salvinia } \\
\text { molesta }\end{array}$} & Silfuric acid $2 \% v / v$ & $11.2 \mathrm{~mL} / \mathrm{g} \mathrm{VS}$ & $16.6 \mathrm{~mL} / \mathrm{g}$ VS & $\begin{array}{l}\text { Bottle } \\
0.6 \mathrm{~L}\end{array}$ & [86] \\
\hline & Silfuric acid $4 \% v / v$ & $11.2 \mathrm{~mL} / \mathrm{g}$ VS & $17.4 \mathrm{~mL} / \mathrm{g}$ VS & $\begin{array}{l}\text { Bottle } \\
0.6 \mathrm{~L}\end{array}$ & [86] \\
\hline & Silfuric acid $6 \% v / v$ & $11.2 \mathrm{~mL} / \mathrm{g}$ VS & $17.8 \mathrm{~mL} / \mathrm{g}$ VS & $\begin{array}{l}\text { Bottle } \\
0.6 \mathrm{~L}\end{array}$ & [86] \\
\hline Switchgrass & Sodium hydroxide $7 \mathrm{~g} / \mathrm{L}$ & $112.4 \mathrm{~mL} / \mathrm{g} \mathrm{VS}$ & $132.5112 .4 \mathrm{~mL} / \mathrm{g}$ VS & $\begin{array}{l}\text { Bottle } \\
0.5 \mathrm{~L}\end{array}$ & [75] \\
\hline \multirow[b]{2}{*}{ Water hyacinth } & Silfuric acid $5 \% v / v ; 60$ min residence time & $58 \mathrm{~mL} / \mathrm{g}$ VS & $64 \mathrm{~mL} / \mathrm{g} \mathrm{VS}$ & Flask $1 \mathrm{~L}$ & [129] \\
\hline & $\begin{array}{l}\text { NMMO } 85 \% \\
120^{\circ} \mathrm{C} ; 3 \mathrm{~h}\end{array}$ & $274 \mathrm{~mL} / \mathrm{g}$ VS & $304 \mathrm{~mL} / \mathrm{g}$ VS & $\begin{array}{c}\text { Serum bottles } \\
0.125 \mathrm{~L}\end{array}$ & [130] \\
\hline \multirow{3}{*}{ Wheat straw } & $\begin{array}{l}\text { Ethanol } 50 \% \\
180^{\circ} \mathrm{C} ; 1 \mathrm{~h}\end{array}$ & $274 \mathrm{~mL} / \mathrm{g}$ VS & $316 \mathrm{~mL} / \mathrm{g}$ VS & $\begin{array}{c}\text { Serum bottles } \\
0.125 \mathrm{~L}\end{array}$ & [130] \\
\hline & Sodium hydroxide $1.6 \% \mathrm{w} / \mathrm{w} 30 \mathrm{C} ; 24 \mathrm{~h}$ & $274 \mathrm{~mL} / \mathrm{g}$ VS & $315 \mathrm{~mL} / \mathrm{g}$ VS & $\begin{array}{c}\text { Serum bottles } \\
0.125 \mathrm{~L}\end{array}$ & [130] \\
\hline & Citric Acid $0.5 \mathrm{mmol} / \mathrm{g}$ VS substrate & $159.1 \mathrm{~mL} / \mathrm{g}$ VS & $163.7 \mathrm{~mL} / \mathrm{g}$ VS & $\begin{array}{l}\text { Flask } \\
0.25 \mathrm{~L}\end{array}$ & [78] \\
\hline \multirow{2}{*}{ Winert waste } & Hydrogen $0.5 \mathrm{mmol} / \mathrm{g}$ VS substrate peroxide & $171.3 \mathrm{~mL} / \mathrm{g}$ VS & $190.2 \mathrm{~mL} / \mathrm{g}$ VS & $\begin{array}{l}\text { Flask } \\
0.25 \mathrm{~L}\end{array}$ & [78] \\
\hline & Ethanol $0.5 \mathrm{mmol} / \mathrm{g}$ VS substrate & $190.7 \mathrm{~mL} / \mathrm{g} \mathrm{VS}$ & $239.5 \mathrm{~mL} / \mathrm{g}$ VS & $\begin{array}{l}\text { Flask } \\
0.25 \mathrm{~L}\end{array}$ & [78] \\
\hline
\end{tabular}




\subsection{Physicochemical Pretreatments}

Physicochemical methods are used to solubilize lignocellulosic components of the structure based on temperature and moisture content and to make the lignocellulosic material easily exposed for hydrolysis step, and avoiding the formation of inhibitors. Although these methods are more complicated to implement, their significant effect on the pretreatment of lignocellulose feedstock promises high yield in the subsequent bioprocesses [131]. In general, physical pre-treatment requires greater energy expenditure, making it an expensive process and consequently not very profitable on an industrial scale. Therefore, this review focusses on process optimization and the conditions to reduce energy-time-costs of this process.

\subsubsection{Steam Explosion}

Steam explosion consists of exposure to hot steam for few minutes, followed by an explosive decompression of the biomass, which is effective in breakage of the fibrous rigid structure of straw and woody biomass [132,133]. To facilitate auto hydrolysis reactions, the biomass is treated with saturated steam at a temperature of $160-260{ }^{\circ} \mathrm{C}$ and at a corresponding pressure of $0.69-4.83 \mathrm{MPa}$ for several seconds up to few min $[59,133]$. The difference between pretreatment with steam and the explosion with steam, is the rapid depressurization and cooling of biomass at the end of the steam explosion, which causes hydrolysis of hemicellulose into water soluble oligomers or to individual sugars [134]. Nges et al. [135] used steam explosion pretreatment on Miscanthus lutarioriparius under conditions of $0.3 \mathrm{M} \mathrm{NaOH}$ and at $0.5 \mathrm{~mm}$ particle size, and reported $57 \%$ increase in methane yield in comparison with the untreated substrate. Li et al. [136] evaluated steam explosion pretreatment on Miscanthus lutarioriparius under five different conditions: $0.5 \mathrm{MPa} 153{ }^{\circ} \mathrm{C} 5 \mathrm{~min}, 1.0 \mathrm{MPa} 180{ }^{\circ} \mathrm{C} 5 \mathrm{~min}$, $1.5 \mathrm{MPa} 198{ }^{\circ} \mathrm{C} 3 \mathrm{~min}, 1.5 \mathrm{MPa} 198^{\circ} \mathrm{C} 5 \mathrm{~min}$, and $1.5 \mathrm{MPa} 198^{\circ} \mathrm{C} 10 \mathrm{~min}$ to improve the anaerobic biodegradability and reported $5.9 \%, 19.9 \%, 51.3 \%, 49.7 \%$, and $49.8 \%$ increase in biochemical methane potential respectively.

\subsubsection{Hydrothermal}

Of late, hydrothermal pretreatment has gained importance, as it is efficient in penetration of the biomass, cellulose hydration, and removal of hemicellulose and part of lignin. The major advantages are that there is no requirement of chemicals and corrosion-resistant material for the reactor [137]. Typically, it can remove most of hemicellulose and part of lignin in biomass by degrading them into soluble fractions and loosen the recalcitrant structure as well [138]. The temperature is the most important factor influencing the pretreatment effect [139]. Typically, hydrothermal pretreatment is conducted in range of $90-260{ }^{\circ} \mathrm{C}$ [130]. Phuttaro et al. [140] suggested hydrothermal pretreatment at $175{ }^{\circ} \mathrm{C}$ for $15 \mathrm{~min}$ of reaction time on Napier grass increased the methane yield by $25 \%$ than the untreated. They also reported the formation of inhibitors like 5-hydroxymethylfural and furfural at $200{ }^{\circ} \mathrm{C}$, which significantly inhibited methanogenesis. Similarly, Rajput et al. [141] tested 120, 140, 160 , and $180^{\circ} \mathrm{C}$ for pretreatment of wheat straw and established that the optimal temperature for hydrothermal pretreatment of wheat straw was $180^{\circ} \mathrm{C}$, which showed a $53 \%$ increase in the methane yield in comparison with untreated. Hashemi et al. [142] pretreated hydrothermally Safflower straw at 120,150 , and $180^{\circ} \mathrm{C}$ for 1,2 , and $5 \mathrm{~h}$ and the highest biomethane yield was obtained at the least severe pretreatment conditions $\left(120^{\circ} \mathrm{C}\right.$ for $1 \mathrm{~h}$ ), which showed $98.3 \%$ improvement in comparison to the untreated straw. On the other hand, Luo et al. [143] examined hydrothermal pretreatment of rice straw at different temperatures from 90 to $130^{\circ} \mathrm{C}$. Both $100{ }^{\circ} \mathrm{C}$ and $130^{\circ} \mathrm{C}$ pretreatments presented similar methane yield of 127.6 and $124.6 \mathrm{~mL} / \mathrm{g}$ VS, respectively, which were $22.90 \%$ and $19.83 \%$ higher than untreated rice straw. Antwi et al. [144] evaluated hydrothermal pretreatment on cocoa pods residues at temperatures in the range of $155-220^{\circ} \mathrm{C}$ and at reaction time between 5 and $15 \mathrm{~min}$ and reported an optimum methane yield of $526.38 \mathrm{~mL} / \mathrm{g}$ VS at $150{ }^{\circ} \mathrm{C}$ for $15 \mathrm{~min}$ and opined that higher severity conditions resulted in lower biogas yield. 


\subsubsection{Ammonia Fiber Explosion (AFEX)}

AFEX is a physicochemical pretreatment under varying water loading, ammonia loading, reaction temperature, and residence time. In this pretreatment, liquid ammonia and the steam explosion process are applied. The advantage of this process is that it does not require small particle size for efficiency and further, inhibitors are not formed during the process. However, the limitation is that less efficiency has been reported in the pretreatment of high lignin containing biomass [61].

To reduce costs and protect the environment, ammonia is recycled after pretreatment. Wang et al. [145] achieved $99.3 \%$ of efficiency in ammonia removal after pretreatment of wheat straw at $0.70 \%$ ammonia and at $105{ }^{\circ} \mathrm{C}$. They observed the methane yield of $538.1 \mathrm{~mL} / \mathrm{g}$ VS after pretreatment, which was $31.9 \%$ higher than untreated wheat straw. Hashemi et al. [146] carried out a detailed study using $10 \% v / v$ of aqueous ammonia pretreatment on sugarcane bagasse and at varying temperatures in the range of 50 to $70{ }^{\circ} \mathrm{C}$, reaction time of 12 and $24 \mathrm{~h}$ and ethanol addition at different concentrations of 5,25 , and $50 \% v / v$. They reported that the highest methane yield of $299.3 \mathrm{~mL} / \mathrm{g}$ VS compared with $105.6 \mathrm{~mL} / \mathrm{g}$ VS of untreated material was obtained under process conditions of $70{ }^{\circ} \mathrm{C}$ for $12 \mathrm{~h}$ with $10 \%$ ammonia and $50 \%$ ethanol.

The effect of physiochemical treatment on biogas yield is presented in Table 5. It can be observed that steam explosion pretreatment of Miscanthus lutarioriparius at $198^{\circ} \mathrm{C}$ for $3 \mathrm{~min}$ recorded an increase in methane yield of $51 \%$, but no differences were found by increasing the pretreatment time to 5 and $10 \mathrm{~min}$ [135] Luo et al. [143] employed hydrothermal pretreatment of the rice straw at $100^{\circ} \mathrm{C}$ for $10 \mathrm{~min}$ and observed $222 \%$ increase in methane yield.

Table 5. Effect of different physicochemical pretreatments on methane yield from different lignocellulosic biomass.

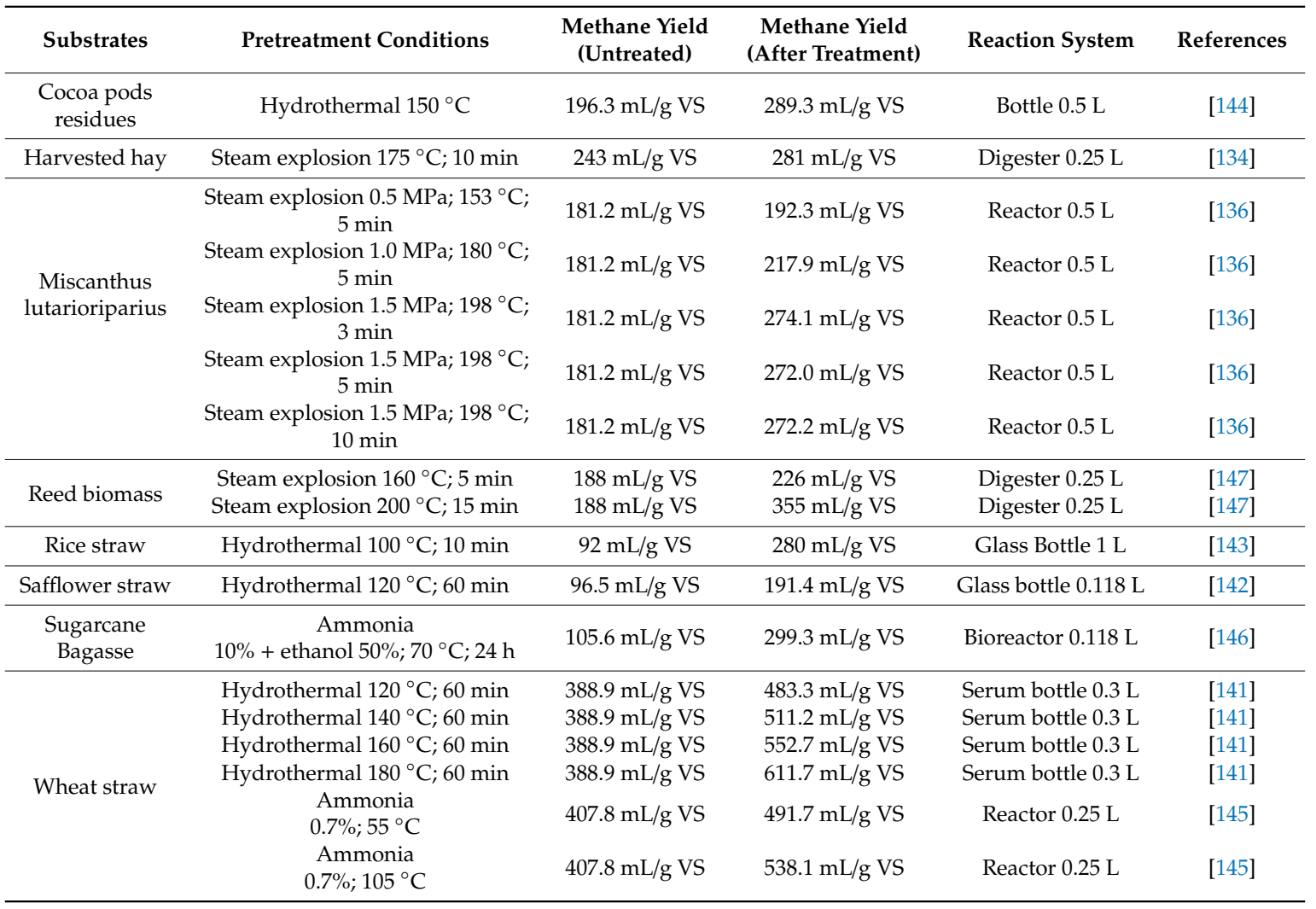

\subsection{Biological Pretreatments}

Biological pretreatment offers an alternative choice to replace chemical pretreatment; however, its very slow reaction rate is unattractive from commercial point of view [148]. Different microorganisms 
are used for lignocellulose pretreatment, such as; white, brown, and soft rot fungi. Although, brown rot fungi participates in lignin decomposition [149], white rot fungi are well known and most effective microorganism for delignification process [150]. In general, most of the fungi degrading lignocellulose secrete accessory enzymes like cellobiose dehydrogenase, aryl alcohol oxidase, glyoxyl oxidase, copper oxidase, and hydrolytic enzymes, which cause the simultaneous or selective degradation of cellulose and hemicellulose along with lignin. These enzymes provide free radicals and intermediates that help in lignin and polysaccharide degradation [151]. Schroyen et al. [152] evaluated the impact of biological pretreatment with different enzymes such as laccase, manganese peroxidase, and versatile peroxidase, at different incubation times- 0,6 , and $24 \mathrm{~h}$. Pretreatments did not yield high concentrations of phenolic compounds, inhibitors of methane production. The laccase enzyme showed $25 \%$ increase in biomethane production after $24 \mathrm{~h}$ of incubation, meanwhile, pretreatment with peroxidase enzymes increased biomethane production by $17 \%$, but aided in reducing the incubation time from 24 to $6 \mathrm{~h}$. Liu et al. [153] evaluated fungal pretreatment of two forest residues, viz., hazel and acacia branches and as well as two agricultural residues, viz., barley straw and sugarcane bagasse using Ceriporiopsis subvermispora in order to improve the methane production. They reported that manganese peroxidase and laccase produced by the fungus increased the methane yield by $100 \%$ in comparison to untreated hazel. Although fungal pretreatments of lignocellulosic biomass are environmentally and economically friendly, it is a relatively time-consuming process and Liu et al. [153] observed that a special bioreactor should be designed to create aerobic and aseptic conditions for fungal pretreatments. It is also reported that selection of substrate specific and as well as effective strain and culture conditions can reduce treatment time and carbohydrate losses [154]. Dollhofer et al. [155] reported that biogas production from lignocellulosic biomass can be accelerated after pretreatment with Neocallimastix frontalis, an anaerobic fungus isolated from rumen fluid of a cow and of a chamois.

The byproducts formed after biological pretreatments normally do not inhibit subsequent hydrolysis, since the pretreatment is carried out at moderate reaction conditions, and also has other environmental benefits like low inputs (energy, chemicals) and outputs (inhibitors and wastes) [156]. However, as mentioned earlier, its process time is long compared to the others [148,157]. As a result, several studies select different microbial populations for hydrolysis of their specific substrates [158]. Shah and Ullah [39] selected strains producing lignin peroxidases and laccases and decreased $48.2 \%$ of lignin from wheat straw within 7 days of batch incubation; and observed $407.1 \%$ increase of the methane yield in comparison with the untreated wheat straw.

Microbial pretreatment, when compared to enzymatic pretreatment, demonstrates much better outcome in anaerobic digestion process due to their higher functional diversity and tolerance to environmental factors-i.e., temperature and $\mathrm{pH}$. Barua et al. [38] isolated bacterial strains from soil (Bordetella muralis VKVVG5), the gut of silverfish (Citrobacter werkmanii VKVVG4), and millipede (Paenibacillus sp. VKVVG1); and employed these bacterial strains to accelerate hydrolysis of water hyacinth. Citrobacter werkmanii VKVVG4 pretreatment of water hyacinth at a density of $109 \mathrm{CFU} / \mathrm{mL}$ for 4 days increased the solubilization by $33.3 \%$. On the other hand, several others report the use of anaerobic lignocellulose degrading consortia. Kong et al. [159] reported that anaerobic consortium TC-5 resulted in $45.7 \%$ degradation of wheat straw and showed an increase of $22.2 \%$ and $36.6 \%$ of methane yield under mesophilic and thermophilic conditions, respectively. Rumen fluid was found to be effective in increasing the yield from rapeseed stems and leaves by $47 \%$ within $24 \mathrm{~h}$ of treatment time [160]. Yuan et al. [19] used a thermophilic microbial consortium MC1 to pretreat the cotton stalk. The results indicated that the concentrations of soluble chemical oxygen demand and volatile organic products increased significantly in the early stages of the pretreatment, reaching the maximum methane yield of $128 \mathrm{~mL} / \mathrm{g}$ VS after 6 days of MC1 pretreatment. However, with $122 \mathrm{~mL} / \mathrm{g}$ VS, the methane yield was not significantly different. Ali et al. [33] observed a $72.6 \%$ increased higher methane yield over control from saw dust treated with a microbial consortium LCDC isolated from rotten sawdust. They also reported a significant reduction of lignocellulose compounds within 10 days of pretreatment. 
Enzymatic pretreatment by using oxidative and hydrolytic enzymes produced by bacteria and fungi such as exo-, endo- glucanases, cellobiase, xylanase, pectinase; ligninolytic enzymes such as laccase, manganese, and versatile peroxidases; as well as $\alpha$-amylases and protease is advantageous in comparison to bacterial/fungal pretreatments [161]. The enzymatic pretreatment method is gaining more interest due to the relatively short reaction time and the low nutrition requirement for the enzymatic reactions. In addition, the enzymatic pretreatment does not require expensive equipment for the processing. However, the activity of the enzymes and the efficiency of their reactions depends on several factors including the composition of the lignocellulosic substrate, temperature, $\mathrm{pH}$, incubation time, and bioreactor configuration [157]. Additionally, the high enzyme cost remains a challenge facing the economic feasibility of this pretreatment methods for improved biogas production at an industrial scale $[157,161]$. However, the efficiency is well documented by Brémond et al. [162], who reported an increase of the methane yield by $111 \%$ from mix of corn stover after $18 \mathrm{~h}$ of reaction time using a blend of cellulase enzymes.

The conditions and effect of biological pretreatment on methane yield from different lignocellulosic substrates is presented in Table 6. In general, biological pretreatment shows an increase up to 50\% in comparison with untreated lignocellulosic biomass.

Table 6. Effect of different biological pretreatments on methane yield from different lignocellulosic biomass.

\begin{tabular}{|c|c|c|c|c|c|}
\hline Substrates & $\begin{array}{l}\text { Pretreatment } \\
\text { Conditions }\end{array}$ & $\begin{array}{l}\text { Methane Yield } \\
\text { (Untreated) }\end{array}$ & $\begin{array}{c}\text { Methane Yield } \\
\text { (After Treatment) }\end{array}$ & $\begin{array}{l}\text { Reaction } \\
\text { System }\end{array}$ & References \\
\hline \multirow{3}{*}{ Corn stover } & $\begin{array}{l}\text { Fungi, Pleurotus eryngii, } \\
30 \text { days }\end{array}$ & $301.5 \mathrm{~mL} / \mathrm{g}$ VS & $360.4 \mathrm{~mL} / \mathrm{g}$ VS & $\begin{array}{l}\text { Bottle } \\
0.25 \mathrm{~L}\end{array}$ & [148] \\
\hline & $\begin{array}{l}\text { Fungi, Pleurotus } \\
\text { ostreatus, } 30 \text { days }\end{array}$ & $294.3 \mathrm{~mL} / \mathrm{g}$ VS & $300.6 \mathrm{~mL} / \mathrm{g}$ VS & $\begin{array}{l}\text { Bottle } \\
0.25 \mathrm{~L}\end{array}$ & [148] \\
\hline & $\begin{array}{c}\text { Fungi, Trametes } \\
\text { versicolor, } 30 \text { days }\end{array}$ & $362.2 \mathrm{~mL} / \mathrm{g}$ VS & $222.83 \mathrm{~mL} / \mathrm{g}$ VS & $\begin{array}{l}\text { Bottle } \\
0.25 \mathrm{~L}\end{array}$ & [148] \\
\hline $\begin{array}{l}\text { Rapeseed stems } \\
\text { and leaves }\end{array}$ & Rumen fluid, $24 \mathrm{~h}$ & $485.5 \mathrm{~mL} / \mathrm{g}$ VS & $507.9 \mathrm{~mL} / \mathrm{g}$ VS & $\begin{array}{l}\text { Reactor } \\
1 \mathrm{~L}\end{array}$ & [160] \\
\hline Sawdust & $\begin{array}{c}\text { Microbial consortium, } \\
10 \text { days }\end{array}$ & $89.9 \mathrm{~mL} / \mathrm{g}$ VS & $155.2 \mathrm{~mL} / \mathrm{g} \mathrm{VS}$ & $\begin{array}{l}\text { Digester } \\
5 \mathrm{~L}\end{array}$ & [33] \\
\hline Water Hyacinth & $\begin{array}{c}\text { Microbial, Citrobacter } \\
\text { werkmanii VKVVG4 } \\
109 \mathrm{cfu} / \mathrm{mL} ; 4 \text { days }\end{array}$ & $338 \mathrm{~mL} / \mathrm{g}$ VS & $373 \mathrm{~mL} / \mathrm{g}$ VS & $\begin{array}{l}\text { Bottle } \\
1 \mathrm{~L}\end{array}$ & [38] \\
\hline \multirow[b]{2}{*}{ Wheat straw } & $\begin{array}{l}\text { Fungus culture, } \\
0.3 \text { OD; } 7 \text { days }\end{array}$ & $78.1 \mathrm{~mL} / \mathrm{g}$ VS & $396.1 \mathrm{~mL} / \mathrm{g}$ VS & - & [118] \\
\hline & $\begin{array}{c}\text { Microbial consortium, } \\
\text { TC-5, } \\
12 \text { days }\end{array}$ & $229.8 \mathrm{~mL} / \mathrm{g}$ VS & $314 \mathrm{~mL} / \mathrm{g}$ VS & $\begin{array}{l}\text { Reactor } \\
0.18 \mathrm{~L}\end{array}$ & [159] \\
\hline \multirow{2}{*}{$\begin{array}{l}\text { Willow } \\
\text { sawdust }\end{array}$} & $\begin{array}{c}\text { Fungal, Leiotrametes } \\
\text { menziesii, } 30 \text { days }\end{array}$ & $95.5 \mathrm{~mL} / \mathrm{g}$ VS & $62.4 \mathrm{~mL} / \mathrm{g} \mathrm{VS}$ & $\begin{array}{l}\text { Serum } \\
\text { bottle } \\
0.16 \mathrm{~L}\end{array}$ & [40] \\
\hline & $\begin{array}{l}\text { Fungal, Abortiporus } \\
\text { biennis, } 30 \text { days }\end{array}$ & $95.5 \mathrm{~mL} / \mathrm{g}$ VS & $136.7 \mathrm{~mL} / \mathrm{g} \mathrm{VS}$ & $\begin{array}{l}\text { Serum } \\
\text { bottle } \\
0.16 \mathrm{~L}\end{array}$ & [40] \\
\hline
\end{tabular}

\subsection{Other Pretreatments}

Several other pretreatments such as ozonolysis, microwave irradiation, and high voltage pulse discharge have also been reported recently to increase the methane yield from lignocellulosic biomass. Ozonolysis is one of the most promising chemical oxidative pretreatments for lignin degradation with minimal losses of hemicellulose and cellulose contents [163], but most of the reported literature is on 
its application related to pulp. Dománski et al. [164] reported a specific methane production of 291 $\mathrm{LCH}_{4} / \mathrm{kg}$ VS using ozonolysis pretreatment of rye straw with an ozone dose of $100 \mathrm{~g} \mathrm{O}_{3} / \mathrm{m}^{3}$ for $60 \mathrm{~min}$.

Microwave irradiation is known as an efficient technique in disrupting complex structures such as sludge and thereby increases the accessibility and bioavailability to enhance methane production [165]. Zhao et al. [166] reported a methane yield of $221 \mathrm{~mL} / \mathrm{g}$ of water hyacinth after a pretreatment of $500 \mathrm{~W}$ for $14.6 \mathrm{~min}$, which was about $38.3 \%$ more than the substrate pretreated with hot water. However, after an economic analysis, they reported that it is not economically viable. Previously, Pellera and Gidarakos [167] observed that pretreatment of winery waste, cotton gin waste, olive pomace, and juice industry waste by microwave did not show an increase in methane production. However, they observed that structural changes in cotton gin waste and olive pomace, whereas increased solubilization in the case of winery and juice industry waste. Kainthola et al. [168] evaluated the microwave pretreatment at different temperatures and exposure time, the ranges were $130-230^{\circ} \mathrm{C}$ and $2-5 \mathrm{~min}$, respectively. They obtained a specific methane yield of $325.7 \mathrm{~mL} / \mathrm{g}$ VS of microwave pretreated rice straw, which was equivalent to a total net energy gain of $2388.5 \mathrm{~J} / \mathrm{g}$ VS. They further reported that high heating rate with less residence time reduced the formation of inhibitory compounds.

High voltage pulse discharge has been a promising strategy for pretreatment of wastes and can shorten the processing time, from $24 \mathrm{~h}$ to $30 \mathrm{~min}$, and the operation is more convenient than acid and alkaline pretreatments in the sense that there is no need to adjust $\mathrm{pH}$ after pretreatment [169]. Zou et al. [169] showed that methane production was higher by $50 \%$ from on food wastes in comparison with acid and alkaline pretreatments. Baijuan et al. [170] reported a gas production of $9587 \mathrm{~mL}, 27 \%$ higher than the untreated hybrid Pennisetum by applying a high voltage plus discharge for $60 \mathrm{~min}$.

\subsection{Combined Pretreatments}

An appropriate combined pretreatment would not only improve the digestibility of lignocellulosic materials at a relatively low operating cost but also maximize the utilization of the lignocellulosic components [171]. A number of studies have shown that a combination of two pretreatments such as biological pretreatment with chemical or physical methods is more effective when compared to pretreatments with a chemical or biological method alone [172]. Although fungal pretreatment can provide a cost-effective feasibility for methane production, the low rate of hydrolysis and the reaction time of the process have made this method commercially inapplicable, but in combination with other pretreatment methods like mechanical or chemical there is an improvement to overall process productivity [173]. A study conducted by Mustafa et al. [174] used a combination of milling and biological pretreatment of rice straw with Pleurotus ostreatus, resulted in $30.4 \%$ of lignin removal and reported a methane yield of $258 \mathrm{~mL} / \mathrm{g} \mathrm{VS}$, which is equivalent to $165 \%$ increase in methane yield compared to untreated rice straw. Gomez-Tovar et al. [27] used mild acid pretreatment $(2 \%$ of $\mathrm{HCl})$ in combination with an enzymatic pretreatment, which solubilized $96.8 \%$ of hemicellulose, $77.2 \%$ of cellulose, and $42.2 \%$ of lignin from oat straw; additionally, this combination produced a variety of sugars that could serve as substrates in the biomethanation process.

In general, chemical, physicochemical, or biological pretreatment is followed after mechanical pretreatment to improve the efficiency [75]. However, the combination is not restricted to different types of pretreatment, it can be even the use of two different chemical treatments; i.e., pretreatment with dilute acid for hemicellulose hydrolysis and then a pretreatment with dilute alkali for lignin removal; or alkaline hydrogen peroxide pretreatment is the combination of alkali reagent plus oxidant reagent [60]. Chen et al. [175] suggested combining dilute acid treatment of lignocellulose with dilute alkali to eliminates the need for acid/ base neutralization of lignocellulose biomass, which could also reduce the inhibitory effect of degradation products. The most common pretreatment combinations are physicochemical and thermochemical [176]. Sharma et al. [177] compared dilute acid and alkaline pretreatment, both at temperature of $150{ }^{\circ} \mathrm{C}$ and reported the maximum yield of $38 \mathrm{~g} / \mathrm{L}$ of reducing sugars at $0.8 \mathrm{M}$ sodium hydroxide after $30 \mathrm{~min}$ of incubation time, compared to $31 \mathrm{~g} / \mathrm{L}$ of reducing sugars using dilute acid. 
In some cases, even a combination of three pretreatments can be efficient. Moset et al. [97] combined mechanical, thermal, and chemical pretreatments for wheat straw. The advantage of the combination of three pretreatments was that there is no need for vigorous mechanical pretreatment with regard to particle size, reduced the concentration of chemicals required and low temperature process is sufficient to achieve greater efficiency. It clearly suggests that combination of right pretreatment conditions help to improve the energy and the economic balance of pretreatment step.

Table 7 summarizes the pretreatments addressed in which the mechanism of action on lignocellulosic biomass is pointed out, as well as the percentage of improvement for each. It can be seen that mechanical pretreatment improves up to $83 \%$ methane yield and can be seen as a pretreatment to be carried out in the first instance, to subsequently combine with other pretreatment to achieve a greater improvement.

Table 7. A brief summary on the effect of pretreatment methods on methane yield from lignocellulosic biomass.

\begin{tabular}{|c|c|c|c|c|}
\hline \multicolumn{2}{|c|}{ Pretreatment Method } & Mechanism of Action & $\begin{array}{l}\text { Methane Yield } \\
\text { Increase (\%) } \\
\text { (Substrate) }\end{array}$ & References \\
\hline Mechanical & $\begin{array}{l}\text { Milling, chipping, } \\
\text { grinding }\end{array}$ & $\begin{array}{l}\text { Increases accessibility and surface } \\
\text { area. Reduces the crystallinity of } \\
\text { cellulose }\end{array}$ & $\begin{array}{c}\text { Up to } 83 \\
\text { (Wheat straw) }\end{array}$ & [73] \\
\hline \multirow{5}{*}{ Chemical } & Acid & Hydrolyze hemicellulose & $\begin{array}{c}\text { Up to } 74 \\
\text { (Corn straw) }\end{array}$ & [18] \\
\hline & Alkaline & $\begin{array}{l}\text { Lignin removal, decrease of } \\
\text { polymerization degree, and } \\
\text { crystallinity of cellulose }\end{array}$ & $\begin{array}{l}\text { Up to } 105 \\
\text { (Corn straw) }\end{array}$ & [18] \\
\hline & Organosolv & $\begin{array}{l}\text { Allow isolation of each } \\
\text { lignocellulose component }\end{array}$ & $\begin{array}{l}\text { Up to } 400 \\
\text { (Softwood spruce, } \\
\text { rice straw and } \\
\text { triticale straw) }\end{array}$ & [107] \\
\hline & Ionic liquids & $\begin{array}{l}\text { Disrupt lignin and decrystallize the } \\
\text { cellulose }\end{array}$ & $\begin{array}{c}\text { Up to } 97 \\
\text { (Water hyacinth) }\end{array}$ & [35] \\
\hline & $\begin{array}{l}\text { Alkaline hydrogen } \\
\text { peroxide }\end{array}$ & $\begin{array}{l}\text { Lignin removal and improves } \\
\text { enzymatic digestibility }\end{array}$ & $\begin{array}{l}\text { Up to } 115 \\
\text { (Corn straw) }\end{array}$ & [18] \\
\hline \multirow{3}{*}{ Physiochemical } & Steam explosion & $\begin{array}{l}\text { Hydrolyze hemicellulose and } \\
\text { breakage the lignocellulos structure }\end{array}$ & $\begin{array}{c}\text { Up to } 88 \\
\text { (Reed biomass) }\end{array}$ & [147] \\
\hline & Hydrothermal & Ligning and hemicellulose removal & $\begin{array}{l}\text { Up to } 204 \\
\text { (Rice straw) }\end{array}$ & [143] \\
\hline & AFEX & $\begin{array}{c}\text { Lignin removal, decrystallize } \\
\text { cellulosa, and hydrolyze } \\
\text { hemicellulose }\end{array}$ & $\begin{array}{c}\text { Up to } 183 \\
\text { (Sugarcane bagasse) }\end{array}$ & [146] \\
\hline Biological & $\begin{array}{l}\text { Fungal, } \\
\text { microbial, } \\
\text { enzymatic }\end{array}$ & $\begin{array}{l}\text { Delignification process and lignin } \\
\text { decomposition }\end{array}$ & $\begin{array}{c}\text { Up to } 400 \\
\text { (Wheat straw) }\end{array}$ & [39] \\
\hline
\end{tabular}

\subsection{Limitations}

It can be observed that the efficiency of pretreatment methods depends on the feedstock and its composition. It is a complex issue to determine the optimal pretreatment method(s) of lignocellulosic biomass. Regardless of the pretreatment method to be employed, the particle size reduction of lignocellulosic biomass is the most common primary pretreatment method employed. Though, in general, the mechanical pretreatment is significantly related to increase methane yield, one of the disadvantages of mechanical process is its inability to remove the lignin, a critical barrier with regard to bioavailability of carbohydrates for biomethanation. Neumann et al. [176] suggested that lignocellulosic biomass must be reduced to 1-2 $\mathrm{mm}$ to eliminate limitations during hydrolysis; however, size reduction is a very expensive operation that consumes about $33 \%$ of the total electricity demand 
for the whole process. Considering the high energy requirement of mechanical pretreatment and the rise of energy cost, it is not economically sustainable. Thus, reducing the energy requirements and increasing efficiency of grinding and milling of biomass would help to improve the economics of the whole process.

In the case of chemical pretreatment, cost of reagents, and operation such as the extra step for neutralization and the requirement for corrosion resistant reactors are the known limitations [178]. Additionally, the formation of inhibitory compounds is a point to be considered since it can inhibit or significantly reduce the conversion efficiency of hydrolyzates of lignocellulosic biomass to methane. Thus, achieving higher efficiency and lowering the formation of inhibitory compounds at by combining lower concentration of chemical reagents with other pretreatments could aid in cost reduction. In the case of alkali pretreatment, it is effective in solubilization of lignin and the presence of a small amount of residual alkali in the treated biomass aids in neutralizing the $\mathrm{pH}$ reduction during the acidogenesis phase of biomethanation process. Therefore, alkaline pretreatment is more compatible with subsequent anaerobic digestion when compared to acid pretreatment [179].

On the other hand, organic solvents permit the recovery of individual components of lignocellulosic biomass, which make an improvement in capital cost in a biorefinery concept. However, large amounts of downstream wastes and specialized equipment are limitations [102]. Ionic liquids are superior to organic solvents for use in a wide range of applications and in extreme conditions [100], however, the cost and the need for recycling need is a limitation.

In spite of the advantages, biological pretreatments also have several major drawbacks such as specific growth conditions, larger space, longer treatment time, and loss of carbohydrates [178]. Biological pretreatment presents low formation of inhibitory compounds and in general its inhibition effect in the subsequent step of anaerobic digestion is low, when compared with chemical and physiochemical pretreatments.

\subsection{Modeling and Parameters Optimization}

Anaerobic digestion is a multi-step process that can be affected by many process conditions such as $\mathrm{pH}$, temperature, substrate composition, pretreatment method, and digestion time. The optimization of these parameters may ensure high yields of biogas production [180]. Serious consideration should be given to the type of the substrate selected for biogas production because it can affect the amount and quality of the biogas obtained [181].

Although, the lignocellulosic material preparation procedures and pretreatment processes prior to anaerobic digestion are widely investigated, it is not possible to precisely predict the effectiveness of a pretreatment method on certain lignocellulosic substrate as many parameters control the process. However, the use of mathematical models can help to know the interrelationship between the parameters involved and predict the phenomena occurring in the process [182]. The kinetic of the anaerobic digestion provides information about the effect of the inhibitory compounds generated by the pretreatment method on the biodegradability. There are several models of the kinetic analysis of biogas production process being the Gompertz model, a model well known to study the kinetic behavior considering the inhibition parameter in the anaerobic digestion process. The Gompertz equation is used to estimate the biogas yield potential, duration of the lag phase, and maximum biogas production rate. However, when the hydrolysis reaction is the rate-limiting step of the overall process, as in the anaerobic degradation of some lignocellulosic substrates, the first order model is commonly used to estimate the extent of the reaction, and the hydrolysis constant [183].

Dahunsi [64] assessed the possible effect of mechanical pretreatment on the kinetics of the degradability of elephant grass, wild Mexican sunflower, and siam weed during the digestion process using a modified Gompertz equation and reported that the pretreatment reduced the lag period and increased the methane yield by around $22 \%$. They positively correlated the chemical composition of lignocellulosic substrates to their methane potentials by employing single and multiple linear regressions models. Mancini et al. [130] also employed the first order model and a model 
based on modified Gompertz equation to evaluate three different chemical pretreatments and their effect on methane yield from wheat straw. They reported that pretreatment using organic solvent $\mathrm{N}$-methylmorpholine N-oxide (NMMO) showed a significant biomethane production than untreated wheat straw and observed that it could be due to the increase in available surface area due to the pretreatment. Bolado-Rodríguez et al. [183] evaluated different physico-chemical pretreatments on the production of biogas from sugarcane bagasse and wheat straw, and reported that a combination of first order and a modified Gompertz equation provided valid information on the availability of substrate, hydrolysis, and effect of inhibitory compounds. Łukajtis et al. [184] proposed a quadratic equation to optimize process parameters such as concentration of chemicals, temperature, reaction time, and particle size in alkaline pretreatment of Salix viminalis L, based on the results obtained.

Although the biomass type is one of the most important factors in biogas production, it is important to identify the optimal levels of operational parameters of the reactor to increase the methane yield [185]. In this regard, a widely accepted model of the anaerobic process is the ADM1. It describes the process by analyzing 28 parameters and using 19 ordinary differential equations. Unfortunately, it may consume lots of time, and sometimes not possible due to economic and other factors. Rieke et al. [186] developed an alternate model based on four parameters, instead of the 28 of the ADM1 model and only two additive differential equations of first order and reported that the difficulties associated with ADM1 model in switching to different substrate due to the large number of parameters and equations could be overcome in this new model, and further reduced the simulation time needed.

\subsection{Techno-Economic and Environmental Aspects}

Techno-economic feasibility is one of the most important parameters for the commercial viability of biofuels production from lignocellulosic substrates [187]. It is expected that biomass pretreatment cost represents between $19 \%$ and $22 \%$ in a biofuel production chain [118]. Several authors have established techno-economic analysis of different pretreatments to elucidate the profitable conditions under the concept of a biorefinery. Vasco-Correa and Shah [188] compared the techno-economic feasibility of commercial scale fungal pretreatment of four feedstocks-perennial grasses, corn stover, agricultural residues other than corn stover, and hardwood-and observed that the sugar production costs were $1.7,1.6,2.0$, and $2.8 \$ / \mathrm{kg}$ for perennial grasses, corn stover, agricultural residues other than corn stover, and hardwood, respectively. Regarding to chemical pretreatment, Baral and Shah [118] evaluated the production of fermentable sugars from corn stover, switchgrass, and poplar to access the process improvement that would enable the commercialization of ionic liquids pretreatment. Unit sugar production costs $(\$ / \mathrm{kg})$ for ionic liquids pretreatment of corn stover, switchgrass, and poplar were estimated to be $2.7,3.2$, and 3.0, respectively. In addition, other study assessed the economic and technical benefits of steam explosion, dilute sulfuric acid, ammonia fiber explosion, and biological (enzymatic hydrolysis) pretreatments in corn stover [189]. The results showed an estimated sugar production costs of $(\$ / \mathrm{kg}) 0.43,0.42,0.65$, and 1.41 for steam explosion, dilute sulfuric acid, ammonia fiber explosion, and biological (enzymatic hydrolysis) pretreatments, respectively. On the other hand, Brandt et al. [190] provided economic analysis for converting softwood biomass into sugars using a fully mechanical pretreatment, using a three-stage milling process. The concentrated sugar syrup production cost was estimated in $\$ 0.496 / \mathrm{kg}$ of sugar. However, the environmental impact and sustainability of the pretreatment processes are not widely reported. Prasad et al. [191] carried out life cycle assessment analysis on four different pretreatments-viz., liquid hot water, steam explosion, dilute acid, and organosolv—using GaBi software and reported that dilute acid pretreatment performed the worst in all impact categories. Although, other three pretreatments performed similarly, liquid hot water significantly reduced the $\mathrm{CO}_{2}$ emissions and the total sugars production was two times greater than organosolv and steam explosion pretreatments. However, Safarian and Unnthorsson [192] reported that steam explosion pretreatment is the most promising and beneficial technology in terms of economical, environmental and energy points of views and was followed by hot water method for production of bioethanol from paper and timber wastes. Though in terms of technical performance, 
dilute acid pretreatment was ranked highly, it is not preferable due to low energy performance, high production cost and high emission of greenhouse gases. Similarly, dilute alkali treatment also ranked highly on the technical side of bioethanol production, is not preferable due to high emission of greenhouse gases and other environmental impacts. Recently, Soam et al. [193] reported that an addition of low dosage alkali pretreatment to enzymatic pretreatment reduced the enzyme dosage by $23-39 \%$, but observed a negative environmental impact. This clearly suggest that further studies are needed to select right combination of pretreatments and operation conditions of these combinations need to be standardized in order to reduce environmental impacts and costs involved in the pretreatment process. Recently, Rajendran and Murthy [194] also observed that it is important to do a realistic techno-economic and environmental impact analysis of anaerobic digestion processes as there is a need to include process mapping, create a database, and identify profitability indicators and geographic locations of the biogas plants.

\section{Conclusions}

Lignocellulose substrates are the main feedstocks for biogas production and this anaerobic digestion process help in sustainable management of wastes and as well as is one of the main sources of renewable bioenergy. However, the structure of lignocellulosic residues still present technological barriers due to their limited bioavailability and pretreatment of this recalcitrant substrates is a key to improve the performance of anaerobic digestion technology. However, as can be seen, the major limitations are the cost of energy, operational cost, and formation of inhibitory compounds, which significantly affect the downstream bioprocess of generating biogas or other value-added products. Though, combination of different pretreatments offers possible solution, it needs to be specific for the type of substrates and the type of downstream bioprocess to produce bioenergy and other products. To achieve a techno-economic viability of the use of lignocellulose substrates, the idea of integrated biorefineries in which two or more bioproducts are generated in the same platform could be a promising concept.

Author Contributions: Conceptualization, N.B. and J.U.H-B.; Methodology, J.U.H.-B., F.H.-T. and N.B.; Validation, J.U.H.-B., I.O.H.-D.L. and N.B.; formal analyses, J.U.H.-B., I.O.H.-D.L. and M.M.C.-S., Investigation, J.U.H.-B., I.O.H.-D.L., M.M.C.-S. and A.S.-L.; Supervision, N.B.; Writing-original draft preparation, J.U.H.-B.; Writing-review and editing, J.U.H.-B., I.O.H.-D.L., F.H.-T. and N.B.; supervision, N.B.; project administration, N.B.; funding acquisition, N.B.

Funding: This research was funded by Programa Fortalecimiento de la Investigación para el Desarrollo de la Educación y la sociedad (PROFIDES) convocatoria 2017, Secretary of Public Education, Government of Mexico for UACOAH-CA-92 Ciencias Biológicas Aplicadas.

Conflicts of Interest: The authors declare no conflict of interest.

\section{References}

1. Correa, D.F.; Beyer, H.L.; Fargione, J.E.; Hill, J.D.; Possingham, H.P.; Thomas-Hall, S.R.; Schenk, P.M. Towards the Implementation of Sustainable Biofuel Production Systems. Renew. Sustain. Energy Rev. 2019, 107, 250-263. [CrossRef]

2. Andrée, B.P.J.; Diogo, V.; Koomen, E. Efficiency of Second-Generation Biofuel Crop Subsidy Schemes: Spatial Heterogeneity and Policy Design. Renew. Sustain. Energy Rev. 2017, 67, 848-862. [CrossRef]

3. Perin, G.; Jones, P.R. Economic Feasibility and Long-Term Sustainability Criteria on the Path to Enable a Transition from Fossil Fuels to Biofuels. Curr. Opin. Biotechnol. 2019, 57, 175-182. [CrossRef]

4. Li, P.; Sakuragi, K.; Makino, H. Extraction Techniques in Sustainable Biofuel Production: A Concise Review. Fuel Process. Technol. 2019, 193, 295-303. [CrossRef]

5. Alalwan, H.A.; Alminshid, A.H.; Aljaafari, H.A.S. Promising Evolution of Biofuel Generations. Subject Review. Renew. Energy Focus 2019, 28, 127-139. [CrossRef]

6. Scaramuzzino, C.; Garegnani, G.; Zambelli, P. Integrated Approach for the Identification of Spatial Patterns Related to Renewable Energy Potential in European Territories. Renew. Sustain. Energy Rev. 2019, 101, 1-13. [CrossRef] 
7. OECD. Renewable Energy (Indicator). Available online: https://www.oecd-ilibrary.org/energy/renewableenergy/indicator/english_aac7c3f1-en (accessed on 28 August 2019). [CrossRef]

8. Azevedo, S.G.; Sequeira, T.; Santos, M.; Mendes, L. Biomass-Related Sustainability: A Review of the Literature and Interpretive Structural Modeling. Energy 2019, 171, 1107-1125. [CrossRef]

9. Ibarra-Gonzalez, P.; Rong, B.G. A Review of the Current State of Biofuels Production from Lignocellulosic Biomass Using Thermochemical Conversion Routes. Chin. J. Chem. Eng. 2018. [CrossRef]

10. SIAP. Servicio de Información Agroalimentaria y Pesquera. Available online: https://nube.siap.gob.mx/ cierreagricola/ (accessed on 8 August 2019).

11. Delsart, C. Plant Cell Wall: Description, Role in Transport, and Effect of Electroporation. In Handbook of Electroporation; Miklavčič, D., Ed.; Springer International Publishing AG: Cham, Switzerland, 2017; pp. 489-509.

12. Jiang, B.; Zhang, Y.; Guo, T.; Zhao, H.; Jin, Y. Structural Characterization of Lignin and Lignin-Carbohydrate Complex (LCC) from Ginkgo Shells (Ginkgo biloba L.) by Comprehensive NMR Spectroscopy. Polymers 2018, 10, 736. [CrossRef]

13. Chen, J.-H.; Xu, J.K.; Huang, P.-L.; Sun, R.-C. Effect of Alkaline Pretreatment on the Preparation of Regenerated Lignocellulose Fibers from Bamboo Stem. Cellulose 2016, 23, 2727-2739. [CrossRef]

14. Luo, M.; Tian, D.; Shen, F.; Hu, J.; Zhang, Y.; Yang, G.; Zeng, Y.; Deng, S.; Hu, Y. A Comparative Investigation of H2O2-Involved Pretreatments on Lignocellulosic Biomass for Enzymatic Hydrolysis. Biomass Convers. Biorefinery 2019, 9, 321-331. [CrossRef]

15. Pérez-Rodríguez, N.; García-Bernet, D.; Domínguez, J.M. Extrusion and Enzymatic Hydrolysis as Pretreatments on Corn Cob for Biogas Production. Renew. Energy 2017, 107, 597-603. [CrossRef]

16. Dong, C.; Chen, J.; Guan, R.; Li, X.; Xin, Y. Dual-Frequency Ultrasound Combined with Alkali Pretreatment of Corn Stalk for Enhanced Biogas Production. Renew. Energy 2018, 127, 444-451. [CrossRef]

17. Cher, Y.; Stevens, M.A.; Zhu, Y.; Holmes, J.; Xu, H. Understanding the Alkaline Pretreatments Parameters of Corn Stover Enzymatic Saccarification. Biotechnol. Biofuels 2013, 6, 8. [CrossRef]

18. Song, Z.; Yang, G.; Liu, X.; Yan, Z.; Yuan, Y.; Liao, Y. Comparison of Seven Chemical Pretreatments of Corn Straw for Improving Methane Yield by Anaerobic Digestion. PLoS ONE 2014, 9, e93801. [CrossRef]

19. Yuan, X.; Wen, B.; Cui, Z.; Ma, L.; Zhou, D.; Kuang, M.; Yang, W. Enhancing Anaerobic Digestion of Cotton Stalk by Pretreatment with a Microbial Consortium (MC1). Bioresour. Technol. 2016, 207, 293-301. [CrossRef]

20. Xu, J.; Liu, B.; Hou, H.; Hu, J. Pretreatment of Eucalyptus with Recycled Ionic Liquids for Low-Cost Biorefinery. Bioresour. Technol. 2017, 234, 406-414. [CrossRef]

21. Zawawi, A.Z.; Gaik, L.P.; Sebran, N.H.; Othman, J.; Hussain, A.S. An Optimisation Study on Biomass Delignification Process Using Alkaline Wash. Biomass Convers. Biorefinery 2018, 8, 59-68. [CrossRef]

22. Jiang, D.; Ge, X.; Zhang, Q.; Li, Y. Comparison of Liquid Hot Water and Alkaline Pretreatments of Giant Reed for Improved Enzymatic Digestibility and Biogas Energy Production. Bioresour. Technol. 2016, 216, 60-68. [CrossRef]

23. Merino, O.; Almazán, V.; Martínez-Palou, R.; Aburto, J. Screening of Ionic Liquids for Pretreatment of Taiwan Grass in Q-Tube Minireactors for Improving Bioethanol Production. Waste and Biomass Valorization 2017, 8 , 733-742. [CrossRef]

24. Khatri, S.; Wu, S.; Kizito, S.; Zhang, W.; Li, J.; Dong, R. Synergistic Effect of Alkaline Pretreatment and Fe Dosing on Batch Anaerobic Digestion of Maize Straw. Appl. Energy 2015, 158, 55-64. [CrossRef]

25. Tsapekos, P.; Kougias, P.G.; Angelidaki, I. Mechanical Pretreatment for Increased Biogas Production from Lignocellulosic Biomass; Predicting the Methane Yield from Structural Plant Components. Waste Manag. 2018, 78, 903-910. [CrossRef]

26. Thomas, H.L.; Arnoult, S.; Brancourt-Hulmel, M.; Carrère, H. Methane Production Variability According to Miscanthus Genotype and Alkaline Pretreatments at High Solid Content. Bioenergy Res. 2019, 12, 325-337. [CrossRef]

27. Gomez-Tovar, F.; Celis, L.B.; Razo-Flores, E.; Alatriste-Mondragón, F. Chemical and Enzymatic Sequential Pretreatment of Oat Straw for Methane Production. Bioresour. Technol. 2012, 116, 372-378. [CrossRef]

28. Charnnok, B.; Sakdaronnarong, C.; Sinbuathong, N. Hydrothermal Pretreatment with Sulfonated Bentonite Catalyst Enhances Potassium Removal and Bioconversion of Oil Palm Empty Fruit Bunch to Sugar and Biohydrogen. Biomass Convers. Biorefinery 2019, 9, 389-399. [CrossRef] 
29. Salehian, P.; Karimi, K.; Zilouei, H.; Jeihanipour, A. Improvement of Biogas Production from Pine Wood by Alkali Pretreatment. Fuel 2013, 106, 484-489. [CrossRef]

30. Cabrera, E.; Muñoz, M.J.; Martín, R.; Caro, I.; Curbelo, C.; Díaz, A.B. Alkaline and Alkaline Peroxide Pretreatments at Mild Temperature to Enhance Enzymatic Hydrolysis of Rice Hulls and Straw. Bioresour. Technol. 2014, 167, 1-7. [CrossRef]

31. Mustafa, A.M.; Poulsen, T.G.; Sheng, K. Fungal Pretreatment of Rice Straw with Pleurotus Ostreatus and Trichoderma Reesei to Enhance Methane Production under Solid-State Anaerobic Digestion. Appl. Energy 2016, 180, 661-671. [CrossRef]

32. Smuga-Kogut, M.; Zgórska, K.; Szymanowska-Powałowska, D. Influence of the Crystalline Structure of Cellulose on the Production of Ethanol from Lignocellulose Biomass. Int. Agrophys. 2016, 30, 83-88. [CrossRef]

33. Ali, S.S.; Abomohra, A.E.-F.; Sun, J. Effective Bio-Pretreatment of Sawdust Waste with a Novel Microbial Consortium for Enhanced Biomethanation Biofuels Institute, School of the Environment and Safety Engineering, Jiangsu. Bioresour. Technol. 2017, 238, 425-432. [CrossRef]

34. Hernández-Beltrán, J.U.; Hernández-Escoto, H. Enzymatic Hydrolysis of Biomass at High-Solids Loadings through Fed-Batch Operation. Biomass Bioenergy 2018, 119, 191-197. [CrossRef]

35. Gao, J.; Chen, L.; Yuan, K.; Huang, H.; Yan, Z. Ionic Liquid Pretreatment to Enhance the Anaerobic Digestion of Lignocellulosic Biomass. Bioresour. Technol. 2013, 150, 352-358. [CrossRef]

36. Nosratpour, M.J.; Karimi, K.; Sadeghi, M. Improvement of Ethanol and Biogas Production from Sugarcane Bagasse Using Sodium Alkaline Pretreatments. J. Environ. Manag. 2018, 226, 329-339. [CrossRef]

37. Monlau, F.; Barakat, A.; Steyer, J.P.; Carrere, H. Comparison of Seven Types of Thermo-Chemical Pretreatments on the Structural Features and Anaerobic Digestion of Sunflower Stalks. Bioresour. Technol. 2012, 120, 241-247. [CrossRef]

38. Barua, V.B.; Goud, V.V.; Kalamdhad, A.S. Microbial Pretreatment of Water Hyacinth for Enhanced Hydrolysis Followed by Biogas Production. Renew. Energy 2018, 126, 21-29. [CrossRef]

39. Shah, T.A.; Ullah, R. Pretreatment of Wheat Straw with Ligninolytic Fungi for Increased Biogas Productivity. Int. J. Environ. Sci. Technol. 2019, 1-12. [CrossRef]

40. Alexandropoulou, M.; Antonopoulou, G.; Fragkou, E.; Ntaikou, I.; Lyberatos, G. Fungal Pretreatment of Willow Sawdust and Its Combination with Alkaline Treatment for Enhancing Biogas Production. J. Environ. Manag. 2017, 203, 704-713. [CrossRef]

41. Marriott, P.E.; Gómez, L.D.; McQueen-Mason, S.J. Unlocking the Potential of Lignocellulosic Biomass through Plant Science. New Phytol. 2016, 209, 1366-1381. [CrossRef]

42. Chundawat, S.P.S.; Bellesia, G.; Uppugundla, N.; Da Costa Sousa, L.; Gao, D.; Cheh, A.M.; Agarwal, U.P.; Bianchetti, C.M.; Phillips, G.N.; Langan, P.; et al. Restructuring the Crystalline Cellulose Hydrogen Bond Network Enhances Its Depolymerization Rate. J. Am. Chem. Soc. 2011, 133, 11163-11174. [CrossRef]

43. Schneider, R.; Persson, S. Another Brick in the Wall. Science 2015, 350, 156-158. [CrossRef]

44. Hachem, K.; Faugeron, C.; Kaid-Harche, M.; Gloaguen, V. Structural Investigation of Cell Wall Xylan Polysaccharides from the Leaves of Algerian Argania spinosa. Molecules 2016, 21, 1587. [CrossRef]

45. Chen, H. Chemical Composition and Structure of Natural Lignocellulose. In Biotechnology of Lignocellulose: Theory and Practice; Chemical Industry Press: Beijing, China; Springer Science+Business Media: Dordrecht, The Netherlands, 2014; pp. 1-511. [CrossRef]

46. Vanholme, R.; Demedts, B.; Morreel, K.; Ralph, J.; Boerjan, W. Lignin Biosynthesis and Structure. Plant Physiol. 2010, 153, 895-905. [CrossRef]

47. Uzal, E.N.; Gómez Ros, L.V.; Pomar, F.; Bernal, M.A.; Paradela, A.; Albar, J.P.; Ros Barceló, A. The Presence of Sinapyl Lignin in Ginkgo biloba Cell Cultures Changes Our Views of the Evolution of Lignin Biosynthesis. Physiol. Plant. 2009, 135, 196-213. [CrossRef]

48. Zhao, Q.; Wang, H.; Yin, Y.; Xu, Y.; Chen, F.; Dixon, R.A. Syringyl Lignin Biosynthesis Is Directly Regulated by a Secondary Cell Wall Master Switch. Proc. Natl. Acad. Sci. USA 2010, 107, 14496-14501. [CrossRef]

49. Bekchanov, M.; Mondal, M.A.H.; De Alwis, A.; Mirzabaev, A. Why Adoption Is Slow despite Promising Potential of Biogas Technology for Improving Energy Security and Mitigating Climate Change in Sri Lanka? Renew. Sustain. Energy Rev. 2019, 105, 378-390. [CrossRef] 
50. Montañez-Hernández, L.E.; Hernández-De Lira, I.O.; Rafael-Galindo, G.; Madariaga, M.L.F.; Balagurusamy, N. Sustainable Production of Biogas from Renewable Sources: Global Overview, Scale Up Opportunities and Potential Market Trends. In Sustainable Biotechnology-Enzymatic Resources of Renewable Energy; Singh, O.V., Chandel, A.K., Eds.; Springer International Publishing AG: Cham, Switzerland, 2018; pp. 325-354. [CrossRef]

51. Curto, D.; Martín, M. Renewable Based Biogas Upgrading. J. Clean. Prod. 2019, 224, 50-59. [CrossRef]

52. Parsaee, M.; Kiani, M.K.D.; Karimi, K. A Review of Biogas Production from Sugarcane Vinasse. Biomass Bioenergy 2019, 122, 117-125. [CrossRef]

53. Barbera, E.; Menegon, S.; Banzato, D.; D'Alpaos, C.; Bertucco, A. From Biogas to Biomethane: A Process Simulation-Based Techno-Economic Comparison of Different Upgrading Technologies in the Italian Context. Renew. Energy 2019, 135, 663-673. [CrossRef]

54. Paul, S.; Dutta, A. Challenges and Opportunities of Lignocellulosic Biomass for Anaerobic Digestion. Resour. Conserv. Recycl. 2018, 130, 164-174. [CrossRef]

55. Achinas, S.; Achinas, V.; Euverink, G.J.W. A Technological Overview of Biogas Production from Biowaste. Engineering 2017, 3, 299-307. [CrossRef]

56. Rajendran, K.; Drielak, E.; Varma, V.S.; Muthusamy, S.; Kumar, G. Updates on the Pretreatment of Lignocellulosic Feedstocks for Bioenergy Production-A Review. Biomass Convers. Biorefinery 2018, 8, 471-483. [CrossRef]

57. Karimi, K.; Taherzadeh, M.J. A Critical Review on Analysis in Pretreatment of Lignocelluloses: Degree of Polymerization, Adsorption/Desorption, and Accessibility. Bioresour. Technol. 2016, 203, 348-356. [CrossRef]

58. Mupondwa, E.; Li, X.; Tabil, L.; Sokhansanj, S.; Adapa, P. Status of Canada's Lignocellulosic Ethanol: Part I: Pretreatment Technologies. Renew. Sustain. Energy Rev. 2017, 72, 178-190. [CrossRef]

59. Bhutto, A.W.; Qureshi, K.; Harijan, K.; Abro, R.; Abbas, T.; Bazmi, A.A.; Karim, S.; Yu, G. Insight into Progress in Pre-Treatment of Lignocellulosic Biomass. Energy 2017, 122, 724-745. [CrossRef]

60. Lindner, J.; Zielonka, S.; Oechsner, H.; Lemmer, A. Effects of Mechanical Treatment of Digestate after Anaerobic Digestion on the Degree of Degradation. Bioresour. Technol. 2015, 178, 194-200. [CrossRef]

61. Kumari, D.; Singh, R. Pretreatment of Lignocellulosic Wastes for Biofuel Production: A Critical Review. Renew. Sustain. Energy Rev. 2018, 90, 877-891. [CrossRef]

62. Veluchamy, C.; Kalamdhad, A.S. Influence of Pretreatment Techniques on Anaerobic Digestion of Pulp and Paper Mill Sludge: A Review. Bioresour. Technol. 2017, 245, 1206-1219. [CrossRef]

63. Rodriguez, C.; Alaswad, A.; El-Hassan, Z.; Olabi, A.G. Mechanical Pretreatment of Waste Paper for Biogas Production. Waste Manag. 2017, 68, 157-164. [CrossRef]

64. Dahunsi, S. Mechanical Pretreatment of Lignocelluloses for Enhanced Biogas Production: Methane Yield Prediction from Biomass Structural Components. Bioresour. Technol. 2019, 280, 18-26. [CrossRef]

65. Dumas, C.; Damasceno, G.S.G.; Abdellatif, B.; Carrère, H.; Steyer, J.P.; Rouau, X. Effects of Grinding Processes on Anaerobic Digestion of Wheat Straw. Ind. Crops Prod. 2015, 74, 450-456. [CrossRef]

66. Sharma, S.K.; Mishra, I.M.; Sharma, M.P.; Saini, J.S. Effect of Particle Size on Biogas Generation from Biomass Residues. Biomass 1988, 17, 251-263. [CrossRef]

67. De la Rubia, M.A.; Fernández-Cegrí, V.; Raposo, F.; Borja, R. Influence of Particle Size and Chemical Composition on the Performance and Kinetics of Anaerobic Digestion Process of Sunflower Oil Cake in Batch Mode. Biochem. Eng. J. 2011, 58-59, 162-167. [CrossRef]

68. Chandra, R.; Takeuchi, H.; Hasegawa, T.; Vijay, V.K. Experimental Evaluation of Substrate's Particle Size of Wheat and Rice Straw Biomass on Methane Production Yield. Agric. Eng. Int. CIGR J. 2015, 17, 93-104.

69. Tsapekos, P.; Kougias, P.G.; Angelidaki, I. Biogas Production from Ensiled Meadow Grass; Effect of Mechanical Pretreatments and Rapid Determination of Substrate Biodegradability via Physicochemical Methods. Bioresour. Technol. 2015, 182, 329-335. [CrossRef]

70. Herrmann, C.; Heiermann, M.; Idler, C.; Prochnow, A. Particle Size Reduction during Harvesting of Crop Feedstock for Biogas Production I: Effects on Ensiling Process and Methane Yields. Bioenergy Res. 2012, 5, 926-936. [CrossRef]

71. Krause, M.J.; Chickering, G.W.; Townsend, T.G.; Pullammanappallil, P. Effects of Temperature and Particle Size on the Biochemical Methane Potential of Municipal Solid Waste Components. Waste Manag. 2018, 71, 25-30. [CrossRef] 
72. Tsapekos, P.; Kougias, P.G.; Egelund, H.; Larsen, U.; Pedersen, J.; Trénel, P.; Angelidaki, I. Mechanical Pretreatment at Harvesting Increases the Bioenergy Output from Marginal Land Grasses. Renew. Energy 2017, 111, 914-921. [CrossRef]

73. Menardo, S.; Airoldi, G.; Balsari, P. The Effect of Particle Size and Thermal Pre-Treatment on the Methane Yield of Four Agricultural by-Products. Bioresour. Technol. 2012, 104, 708-714. [CrossRef]

74. Dell'Omo, P.; La Froscia, S. Enhancing Anaerobic Digestion of Wheat Straw through Multistage Milling. Model. Meas. Control C 2018, 79, 127-132. [CrossRef]

75. Frigon, J.; Mehta, P.; Guiot, S.R. Impact of Mechanical, Chemical and Enzymatic Pre-Treatments on the Methane Yield from the Anaerobic Digestion of Switchgrass. Biomass Bioenergy 2012, 36, 1-11. [CrossRef]

76. Nalinga, Y.; Legonda, I. The Effect of Particles Size on Biogas. Int. J. Innov. Res. Technol. Sci. 2016, 4, 9-13.

77. Gupta, A.; Verma, J.P. Sustainable Bio-Ethanol Production from Agro-Residues: A Review. Renew. Sustain. Energy Rev. 2015, 41, 550-567. [CrossRef]

78. Pellera, F.-M.; Gidarakos, E. Chemical Pretreatment of Lignocellulosic Agroindustrial Waste for Methane Production. Waste Manag. 2018, 71, 689-703. [CrossRef]

79. Behera, S.; Arora, R.; Nandhagopal, N.; Kumar, S. Importance of Chemical Pretreatment for Bioconversion of Lignocellulosic Biomass. Renew. Sustain. Energy Rev. J. 2014, 36, 91-106. [CrossRef]

80. Dagnino, E.P.; Chamorro, E.R.; Romano, S.D.; Felissia, F.E.; Area, M.C. Optimization of the Acid Pretreatment of Rice Hulls to Obtain Fermentable Sugars for Bioethanol Production. Ind. Crops Prod. 2013, 42, 363-368. [CrossRef]

81. Badiei, M.; Asim, N.; Jahim, J.M.; Sopian, K. Comparison of Chemical Pretreatment Methods for Cellulosic Biomass. APCBEE Procedia 2014, 9, 170-174. [CrossRef]

82. Saha, B.C.; Iten, L.B.; Cotta, M.A.; Wu, Y.V. Dilute Acid Pretreatment, Enzymatic Saccharification and Fermentation of Wheat Straw to Ethanol. Process Biochem. 2005, 40, 3693-3700. [CrossRef]

83. Saha, B.C.; Cotta, M.A. Comparison of Pretreatment Strategies for Enzymatic Saccharification and Fermentation of Barley Straw to Ethanol. New Biotechnol. 2010, 27, 10-16. [CrossRef]

84. Chen, H.; Liu, J.; Chang, X.; Chen, D.; Xue, Y.; Liu, P.; Lin, H.; Han, S. A Review on the Pretreatment of Lignocellulose for High-Value Chemicals. Fuel Process. Technol. 2017, 160, 196-206. [CrossRef]

85. Kumar, S.; Paritosh, K.; Pareek, N.; Chawade, A.; Vivekanand, V. De-Construction of Major Indian Cereal Crop Residues through Chemical Pretreatment for Improved Biogas Production: An Overview. Renew. Sustain. Energy Rev. 2018, 90, 160-170. [CrossRef]

86. Syaichurrozi, I.; Villta, P.K.; Nabilah, N.; Rusdi, R. Effect of Sulfuric Acid Pretreatment on Biogas Production from Salvinia molesta. J. Environ. Chem. Eng. 2019, 7, 102857. [CrossRef]

87. Germec, M.; Bader, N.B.; Turhan, I. Dilute Acid and Alkaline Pretreatment of Spent Tea Leaves to Determine the Potential of Carbon Sources. Biomass Convers. Biorefinery 2018, 8, 529-544. [CrossRef]

88. Liu, Y.-Y.; Xu, J.-L.; Zhang, Y.; Liang, C.-Y.; He, M.-C.; Yuan, Z.; Xie, J. Reinforced Alkali-Pretreatment for Enhancing Enzymatic Hydrolysis of Sugarcane Bagasse. Fuel Process. Technol. 2016, 143, 1-6. [CrossRef]

89. Park, Y.C.; Kim, J.S. Comparison of Various Alkaline Pretreatment Methods of Lignocellulosic Biomass. Energy 2012, 47, 31-35. [CrossRef]

90. Kim, I.; Han, J.-I. Optimization of Alkaline Pretreatment Conditions for Enhancing Glucose Yield of Rice Straw by Response Surface Methodology. Biomass Bioenergy 2012, 6, 1-8. [CrossRef]

91. Liu, X.; Zicari, S.M.; Liu, G.; Li, Y. Improving the Bioenergy Production from Wheat Straw with Alkaline Pretreatment. Biosyst. Eng. 2015, 140, 59-66. [CrossRef]

92. Kim, J.S.; Lee, Y.Y.; Kim, T.H. A Review on Alkaline Pretreatment Technology for Bioconversion of Lignocellulosic Biomass. Bioresour. Technol. 2016, 199, 42-48. [CrossRef]

93. Ravindran, R.; Jaiswal, A.K. A Comprehensive Review on Pre-Treatment Strategy for Lignocellulosic Food Industry Waste: Challenges and Opportunities. Bioresour. Technol. 2016, 199, 92-102. [CrossRef]

94. Peng, F.; Peng, P.; Xu, F.; Sun, R.-C. Fractional Purification and Bioconversion of Hemicelluloses. Biotechnol. Adv. 2012, 30, 879-903. [CrossRef]

95. Xihui, K.; Yongming, S.; Lianhua, L.; Xiaoying, K.; Zhenhong, Y. Improving Methane Production from Anaerobic Digestion of Pennisetum Hybrid by Alkaline Pretreatment. Bioresour. Technol. 2018, 255, $205-212$. [CrossRef] 
96. Romero-Güiza, M.S.; Wahid, R.; Hernández, V.; Møller, H.; Fernández, B. Improvement of Wheat Straw Anaerobic Digestion through Alkali Pre-Treatment: Carbohydrates Bioavailability Evaluation and Economic Feasibility. Sci. Total Environ. 2017, 595, 651-659. [CrossRef]

97. Moset, V.; Xavier, C.D.A.N.; Feng, L.; Wahid, R.; Møller, H.B. Combined Low Thermal Alkali Addition and Mechanical Pre-Treatment to Improve Biogas Yield from Wheat Straw. J. Clean. Prod. 2018, 172, 1391-1398. [CrossRef]

98. Gu, Y.; Zhang, Y.; Zhou, X. Effect of $\mathrm{Ca}(\mathrm{OH})_{2}$ Pretreatment on Extruded Rice Straw Anaerobic Digestion. Bioresour. Technol. 2015, 196, 116-122. [CrossRef]

99. da Silva, A.R.G.; Errico, M.; Rong, B.G. Evaluation of Organosolv Pretreatment for Bioethanol Production from Lignocellulosic Biomass: Solvent Recycle and Process Integration. Biomass Convers. Biorefinery 2018, 8 , 397-411. [CrossRef]

100. Zhao, X.; Cheng, K.; Liu, D. Organosolv Pretreatment of Lignocellulosic Biomass for Enzymatic Hydrolysis. Appl. Microbiol. Biotechnol. 2009, 82, 815-827. [CrossRef]

101. Zhang, K.; Pei, Z.; Wang, D. Organic Solvent Pretreatment of Lignocellulosic Biomass for Biofuels and Biochemicals: A Review. Bioresour. Technol. 2016, 199, 21-33. [CrossRef]

102. Capecchi, L.; Galbe, M.; Barbanti, L.; Wallberg, O. Combined Ethanol and Methane Production Using Steam Pretreated Sugarcane Bagasse. Ind. Crops Prod. 2015, 74, 255-262. [CrossRef]

103. Chaturvedi, V.; Verma, P. An Overview of Key Pretreatment Processes Employed for Bioconversion of Lignocellulosic Biomass into Biofuels and Value Added Products. 3 Biotech 2013, 3, 415-431. [CrossRef]

104. Agnihotri, S.; Johnsen, I.A.; Bøe, M.S.; Øyaas, K.; Moe, S. Ethanol Organosolv Pretreatment of Softwood (Picea abies) and Sugarcane Bagasse for Biofuel and Biorefinery Applications. Wood Sci. Technol. 2015, 49, 881-896. [CrossRef]

105. Xu, Z.; Huang, F. Pretreatment Methods for Bioethanol Production. Appl. Biochem. Biotechnol. 2014, 174, 43-62. [CrossRef]

106. Amnuaycheewa, P.; Hengaroonprasan, R.; Rattanaporn, K.; Kirdponpattara, S.; Cheenkachorn, K.; Sriariyanun, M. Enhancing Enzymatic Hydrolysis and Biogas Production from Rice Straw by Pretreatment with Organic Acids. Ind. Crops Prod. 2016, 87, 247-254. [CrossRef]

107. Teghammar, A.; Karimi, K.; Horváth, I.S.; Taherzadeh, M.J. Enhanced Biogas Production from Rice Straw, Triticale Straw and Softwood Spruce by NMMO Pretreatment. Biomass Bioenergy 2012, 36, 116-120. [CrossRef]

108. Kabir, M.M.; Niklasson, C.; Taherzadeh, M.J.; Horváth, I.S. Biogas Production from Lignocelluloses by N-Methylmorpholine-N-Oxide (NMMO) Pretreatment: Effects of Recovery and Reuse of NMMO. Bioresour. Technol. 2014, 161, 446-450. [CrossRef]

109. Ostovareh, S.; Karimi, K.; Zamani, A. Efficient Conversion of Sweet Sorghum Stalks to Biogas and Ethanol Using Organosolv Pretreatment. Ind. Crops Prod. 2015, 66, 170-177. [CrossRef]

110. da Silva, A.R.G.; Errico, M.; Rong, B.G. Techno-Economic Analysis of Organosolv Pretreatment Process from Lignocellulosic Biomass. Clean Technol. Environ. Policy 2018, 20, 1401-1412. [CrossRef]

111. Weerachanchai, P.; Leong, S.S.J.; Chang, M.W.; Ching, C.B.; Lee, J.M. Improvement of Biomass Properties by Pretreatment with Ionic Liquids for Bioconversion Process. Bioresour. Technol. 2012, 111, 453-459. [CrossRef]

112. Konda, N.M.; Shi, J.; Singh, S.; Blanch, H.W.; Simmons, B.A.; Klein-Marcuschamer, D. Understanding Cost Drivers and Economic Potential of Two Variants of Ionic Liquid Pretreatment for Cellulosic Biofuel Production. Biotechnol. Biofuels 2014, 7, 1-11. [CrossRef]

113. Trinh, L.T.P.; Lee, Y.J.; Lee, J.W.; Lee, H.J. Characterization of Ionic Liquid Pretreatment and the Bioconversion of Pretreated Mixed Softwood Biomass. Biomass Bioenergy 2015, 81, 1-8. [CrossRef]

114. Weerachanchai, P.; Lee, J.M. Recyclability of an Ionic Liquid for Biomass Pretreatment. Bioresour. Technol. 2014, 169, 336-343. [CrossRef]

115. Kim, H.; Ahn, Y.; Kwak, S.-Y. Comparing the Influence of Acetate and Chloride Anions on the Structure of Ionic Liquid Pretreated Lignocellulosic Biomass. Biomass Bioenergy 2016, 93, 243-253. [CrossRef]

116. Hu, X.; Cheng, L.; Gu, Z.; Hong, Y.; Li, Z.; Li, C. Effects of Ionic Liquid/Water Mixture Pretreatment on the Composition, the Structure and the Enzymatic Hydrolysis of Corn Stalk. Ind. Crops Prod. 2018, 122, 142-147. [CrossRef]

117. Zhang, Q.; Hu, J.; Lee, D.J. Pretreatment of Biomass Using Ionic Liquids: Research Updates. Renew. Energy 2017, 111, 77-84. [CrossRef] 
118. Baral, N.R.; Shah, A. Techno-Economic Analysis of Cellulose Dissolving Ionic Liquid Pretreatment of Lignocellulosic Biomass for Fermentable Sugars Production. Biofuels Bioprod. Biorefin. 2016, 10, 70-88. [CrossRef]

119. Xie, Y.; Ma, C.; Lu, X.; Ji, X. Evaluation of Imidazolium-Based Ionic Liquids for Biogas Upgrading. Appl. Energy 2016, 175, 69-81. [CrossRef]

120. Dutra, E.D.; Santos, F.A.; Alencar, B.R.A.; Reis, A.L.S.; de Souza, R.D.F.R.; Aquino, K.A.D.S.; Morais, M.A.; Menezes, R.S.C. Alkaline Hydrogen Peroxide Pretreatment of Lignocellulosic Biomass: Status and Perspectives. Biomass Convers. Biorefinery 2018, 8, 225-234. [CrossRef]

121. Song, Z.L.; Yag, G.H.; Feng, Y.Z.; Ren, G.X.; Han, X.H. Pretreatment of Rice Straw by Hydrogen Peroxide for Enhanced Methane Yield. J. Integr. Agric. 2013, 12, 1258-1266. [CrossRef]

122. Yuan, Z.; Wen, Y.; Li, G. Production of Bioethanol and Value Added Compounds from Wheat Straw through Combined Alkaline/Alkaline-Peroxide Pretreatment. Bioresour. Technol. 2018, 259, 228-236. [CrossRef]

123. Su, Y.; Du, R.; Guo, H.; Cao, M.; Wu, Q.; Su, R.; Qi, W.; He, Z. Fractional Pretreatment of Lignocellulose by Alkaline Hydrogen Peroxide: Characterization of Its Major Components. Food Bioprod. Process. 2015, 94 , 322-330. [CrossRef]

124. Rabelo, S.C.; Andrade, R.R.; Maciel Filho, R.; Costa, A.C. Alkaline Hydrogen Peroxide Pretreatment, Enzymatic Hydrolysis and Fermentation of Sugarcane Bagasse to Ethanol. Fuel 2014, 136, 349-357. [CrossRef]

125. Ayeni, A.O.; Oyekunle, D.T.; Shodipe, O.C.; Folayan, J.A. Data on the Enzymatic Conversion of Alkaline Peroxide Oxidative Pretreated Sugarcane Bagasse for the Production of Fermentable Sugars. Data Brief 2019, 24, 103867. [CrossRef]

126. Siciliano, A.; Stillitano, M.A.; De Rosa, S. Biogas Production from Wet Olive Mill Wastes Pretreated with Hydrogen Peroxide in Alkaline Conditions. Renew. Energy 2016, 85, 903-916. [CrossRef]

127. Katukuri, N.R.; Fu, S.; He, S.; Xu, X.; Yuan, X.; Yang, Z.; Guo, R.B. Enhanced Methane Production of Miscanthus Floridulus by Hydrogen Peroxide Pretreatment. Fuel 2017, 199, 562-566. [CrossRef]

128. Alencar, B.R.A.; Reis, A.L.S.; de Souza, R.D.F.R.; Morais, M.A.; Menezes, R.S.C.; Dutra, E.D. Recycling the Liquid Fraction of Alkaline Hydrogen Peroxide in the Pretreatment of Corn Stover. Bioresour. Technol. 2017, 241, 928-935. [CrossRef]

129. Sarto, S.; Hildayati, R.; Syaichurrozi, I. Effect of Chemical Pretreatment Using Sulfuric Acid on Biogas Production from Water Hyacinth and Kinetics. Renew. Energy 2019, 132, 335-350. [CrossRef]

130. Mancini, G.; Papirio, S.; Lens, P.N.L.; Esposito, G. Increased Biogas Production from Wheat Straw by Chemical Pretreatments. Renew. Energy 2018, 119, 608-614. [CrossRef]

131. Theuretzbacher, F.; Lizasoain, J.; Lefever, C.; Saylor, M.K.; Enguidanos, R.; Weran, N.; Gronauer, A.; Bauer, A. Steam Explosion Pretreatment of Wheat Straw to Improve Methane Yields: Investigation of the Degradation Kinetics of Structural Compounds during Anaerobic Digestion. Bioresour. Technol. 2015, 179, $299-305$. [CrossRef]

132. Rabemanolontsoa, H.; Saka, S. Various Pretreatments of Lignocellulosics. Bioresour. Technol. 2016, $199,83-91$. [CrossRef]

133. Ullah, K.; Sharma, V.K.; Ahmad, M.; Lv, P.; Krahl, J.; Wang, Z. The Insight Views of Advanced Technologies and Its Application in Bio-Origin Fuel Synthesis from Lignocellulose Biomasses Waste, a Review. Renew. Sustain. Energy Rev. 2018, 82, 3992-4008. [CrossRef]

134. Bauer, A.; Lizasoain, J.; Theuretzbacher, F.; Agger, J.W.; Rincón, M.; Menardo, S.; Saylor, M.K.; Enguídanos, R.; Nielsen, P.J.; Potthast, A.; et al. Steam Explosion Pretreatment for Enhancing Biogas Production of Late Harvested Hay. Bioresour. Technol. 2014, 166, 403-410. [CrossRef]

135. Nges, I.A.; Li, C.; Wang, B.; Xiao, L.; Yi, Z.; Liu, J. Physio-Chemical Pretreatments for Improved Methane Potential of Miscanthus lutarioriparius. Fuel 2016, 166, 29-35. [CrossRef]

136. Li, C.; Liu, G.; Nges, I.A.; Liu, J. Enhanced Biomethane Production from Miscanthus lutarioriparius Using Steam Explosion Pretreatment. Fuel 2016, 179, 267-273. [CrossRef]

137. Chandra, R.; Takeuchi, H.; Hasegawa, T. Hydrothermal Pretreatment of Rice Straw Biomass: A Potential and Promising Method for Enhanced Methane Production. Appl. Energy 2012, 94, 129-140. [CrossRef]

138. Wang, D.; Shen, F.; Yang, G.; Zhang, Y.; Deng, S.; Zhang, J.; Zeng, Y.; Luo, T.; Mei, Z. Can Hydrothermal Pretreatment Improve Anaerobic Digestion for Biogas from Lignocellulosic Biomass? Bioresour. Technol. 2018, 249, 117-124. [CrossRef] 
139. Zhou, X.; Li, Q.; Zhang, Y.; Gu, Y. Effect of Hydrothermal Pretreatment on Miscanthus Anaerobic Digestion. Bioresour. Technol. 2017, 224, 721-726. [CrossRef]

140. Phuttaro, C.; Sawatdeenarunat, C.; Surendra, K.C.; Boonsawang, P.; Chaiprapat, S.; Khanal, S.K. Anaerobic Digestion of Hydrothermally-Pretreated Lignocellulosic Biomass: Influence of Pretreatment Temperatures, Inhibitors and Soluble Organics on Methane Yield. Bioresour. Technol. 2019, 284, 128-138. [CrossRef]

141. Rajput, A.A.; Visvanathan, C. Effect of Thermal Pretreatment on Chemical Composition, Physical Structure and Biogas Production Kinetics of Wheat Straw. J. Environ. Manag. 2018, 221, 45-52. [CrossRef]

142. Hashemi, S.S.; Karimi, K.; Mirmohamadsadeghi, S. Hydrothermal Pretreatment of Safflower Straw to Enhance Biogas Production. Energy 2019, 172, 545-554. [CrossRef]

143. Luo, T.; Huang, H.; Mei, Z.; Shen, F.; Ge, Y.; Hu, G.; Meng, X. Hydrothermal Pretreatment of Rice Straw at Relatively Lower Temperature to Improve Biogas Production via Anaerobic Digestion. Chin. Chem. Lett. 2019, 30, 1219-1223. [CrossRef]

144. Antwi, E.; Engler, N.; Nelles, M.; Schüch, A. Anaerobic Digestion and the Effect of Hydrothermal Pretreatment on the Biogas Yield of Cocoa Pods Residues. Waste Manag. 2019, 88, 131-140. [CrossRef]

145. Wang, D.; Xin, Y.; Shi, H.; Ai, P.; Yu, L.; Li, X.; Chen, S. Closing Ammonia Loop in Efficient Biogas Production: Recycling Ammonia Pretreatment of Wheat Straw. Biosyst. Eng. 2019, 180, 182-190. [CrossRef]

146. Hashemi, S.S.; Karimi, K.; Majid Karimi, A. Ethanolic Ammonia Pretreatment for Efficient Biogas Production from Sugarcane Bagasse. Fuel 2019, 248, 196-204. [CrossRef]

147. Lizasoain, J.; Rincón, M.; Theuretzbacher, F.; Enguídanos, R.; Nielsen, P.J.; Potthast, A.; Zweckmair, T.; Gronauer, A.; Bauer, A. Biogas Production from Reed Biomass: Effect of Pretreatment Using Different Steam Explosion Conditions. Biomass Bioenergy 2016, 95, 84-91. [CrossRef]

148. Wyman, V.; Henríquez, J.; Palma, C.; Carvajal, A. Lignocellulosic Waste Valorisation Strategy through Enzyme and Biogas Production. Bioresour. Technol. 2018, 247, 402-411. [CrossRef]

149. Rouches, E.; Herpoël-Gimbert, I.; Steyer, J.P.; Carrere, H. Improvement of Anaerobic Degradation by White-Rot Fungi Pretreatment of Lignocellulosic Biomass: A Review. Renew. Sustain. Energy Rev. 2016, 59, 179-198. [CrossRef]

150. Raveendran, S.; Parameswaran, B.; Ashok, P. Biological Pretreatment of Lignocellulosic Biomass-An Overview. Bioresour. Technol. 2016, 199, 76-82. [CrossRef]

151. Rudakiya, D.M.; Gupte, A. Degradation of Hardwoods by Treatment of White Rot Fungi and Its Pyrolysis Kinetics Studies. Int. Biodeterior. Biodegrad. 2017, 120, 21-35. [CrossRef]

152. Schroyen, M.; Vervaeren, H.; Van Hulle, S.W.H.; Raes, K. Impact of Enzymatic Pretreatment on Corn Stover Degradation and Biogas Production. Bioresour. Technol. 2014, 173, 59-66. [CrossRef]

153. Liu, X.; Hiligsmann, S.; Gourdon, R.; Bayard, R. Anaerobic Digestion of Lignocellulosic Biomasses Pretreated with Ceriporiopsis subvermispora. J. Environ. Manag. 2017, 193, 154-162. [CrossRef]

154. Van Kuijk, S.J.A.; Sonnenberg, A.S.M.; Baars, J.J.P.; Hendriks, W.H.; Cone, J.W. Fungal Treated Lignocellulosic Biomass as Ruminant Feed Ingredient: A Review. Biotechnol. Adv. 2015, 33, 191-202. [CrossRef]

155. Dollhofer, V.; Dandikas, V.; Dorn-In, S.; Bauer, C.; Lebuhn, M.; Bauer, J. Accelerated Biogas Production from Lignocellulosic Biomass after Pre-Treatment with Neocallimastix Frontalis. Bioresour. Technol. 2018, 264, 219-227. [CrossRef]

156. Rouches, E.; Zhou, S.; Steyer, J.P.; Carrere, H. White-Rot Fungi Pretreatment of Lignocellulosic Biomass for Anaerobic Digestion: Impact of Glucose Supplementation. Process Biochem. 2016, 51, 1784-1792. [CrossRef]

157. Hosseini Koupaie, E.; Dahadha, S.; Bazyar Lakeh, A.A.; Azizi, A.; Elbeshbishy, E. Enzymatic Pretreatment of Lignocellulosic Biomass for Enhanced Biomethane Production-A Review. J. Environ. Manag. 2019, 233, 774-784. [CrossRef]

158. Shrestha, S.; Fonoll, X.; Khanal, S.K.; Raskin, L. Biological Strategies for Enhanced Hydrolysis of Lignocellulosic Biomass during Anaerobic Digestion: Current Status and Future Perspectives. Bioresour. Technol. 2017, 245, 1245-1257. [CrossRef]

159. Kong, X.; Du, J.; Ye, X.; Xi, Y.; Jin, H.; Zhang, M.; Guo, D. Enhanced Methane Production from Wheat Straw with the Assistance of Lignocellulolytic Microbial Consortium TC-5. Bioresour. Technol. 2018, 263, 33-39. [CrossRef]

160. Baba, Y.; Matsuki, Y.; Mori, Y.; Suyama, Y.; Tada, C.; Fukuda, Y.; Saito, M.; Nakai, Y. Pretreatment of Lignocellulosic Biomass by Cattle Rumen Fluid for Methane Production: Bacterial Flora and Enzyme Activity Analysis. J. Biosci. Bioeng. 2017, 123, 489-496. [CrossRef] 
161. Carrere, H.; Antonopoulou, G.; Affes, R.; Passos, F.; Battimelli, A.; Lyberatos, G.; Ferrer, I. Review of Feedstock Pretreatment Strategies for Improved Anaerobic Digestion: From Lab-Scale Research to Full-Scale Application. Bioresour. Technol. 2016, 199, 386-397. [CrossRef]

162. Brémond, U.; de Buyer, R.; Steyer, J.P.; Bernet, N.; Carrere, H. Biological Pretreatments of Biomass for Improving Biogas Production: An Overview from Lab Scale to Full-Scale. Renew. Sustain. Energy Rev. 2018, 90, 583-604. [CrossRef]

163. Travaini, R.; Martín-Juárez, J.; Lorenzo-Hernando, A.; Bolado-Rodríguez, S. Ozonolysis: An Advantageous Pretreatment for Lignocellulosic Biomass Revisited. Bioresour. Technol. 2016, 199, 2-12. [CrossRef]

164. Domański, J.; Marchut-Mikołajczyk, O.; Polewczyk, A.; Januszewicz, B. Ozonolysis of Straw from Secale cereale L. for Anaerobic Digestion. Bioresour. Technol. 2017, 245, 394-400. [CrossRef]

165. Li, Y.; Chen, Y.; Wu, J. Enhancement of Methane Production in Anaerobic Digestion Process: A Review. Appl. Energy 2019, 240, 120-137. [CrossRef]

166. Zhao, B.-H.; Chen, J.; Yu, H.-Q.; Hu, Z.-H.; Yue, Z.-B.; Li, J. Optimization of Microwave Pretreatment of Lignocellulosic Waste for Enhancing Methane Production: Hyacinth as an Example. Front. Environ. Sci. Eng. 2017, 11, 1-9. [CrossRef]

167. Pellera, F.-M.; Gidarakos, E. Microwave Pretreatment of Lignocellulosic Agroindustrial Waste for Methane Production. J. Environ. Chem. Eng. 2016, 5, 352-365. [CrossRef]

168. Kainthola, J.; Shariq, M.; Kalamdhad, A.S.; Goud, V.V. Enhanced Methane Potential of Rice Straw with Microwave Assisted Pretreatment and Its Kinetic Analysis. J. Environ. Manag. 2019, 232, 188-196. [CrossRef]

169. Zou, L.; Ma, C.; Liu, J.; Li, M.; Ye, M.; Qian, G. Pretreatment of Food Waste with High Voltage Pulse Discharge towards Methane Production Enhancement. Bioresour. Technol. 2016, 222, 82-88. [CrossRef]

170. Baijuan, W.; Ting, C.; Xiangdong, Q.; Qi, W.; Yan, Z.; Shunxing, B.; Wen, P.; Bo, F. Effect of High-Voltage Pulsed Electric Field (HPEF) Pretreatment on Biogas Production Rates of Hybrid Pennisetum by Anaerobic Fermentation. Nat. Gas Ind. B 2018, 5, 48-53. [CrossRef]

171. De Bhowmick, G.; Sarmah, A.K.; Sen, R. Lignocellulosic Biorefinery as a Model for Sustainable Development of Biofuels and Value Added Products. Bioresour. Technol. 2018, 247, 1144-1154. [CrossRef]

172. Ponnusamy, V.K.; Nguyen, D.D.; Dharmaraja, J.; Shobana, S.; Banu, J.R.; Saratale, R.G.; Chang, S.W.; Kumar, G. A Review on Lignin Structure, Pretreatments, Fermentation Reactions and Biorefinery Potential. Bioresour. Technol. 2019, 271, 462-472. [CrossRef]

173. Shirkavand, E.; Baroutian, S.; Gapes, D.J.; Young, B.R. Combination of Fungal and Physicochemical Processes for Lignocellulosic Biomass Pretreatment-A Review. Renew. Sustain. Energy Rev. 2016, 54, 217-234. [CrossRef]

174. Mustafa, A.M.; Poulsen, T.G.; Xia, Y.; Sheng, K. Combinations of Fungal and Milling Pretreatments for Enhancing Rice Straw Biogas Production during Solid-State Anaerobic Digestion. Bioresour. Technol. 2017, 224, 174-182. [CrossRef]

175. Chen, X.; Zhai, R.; Shi, K.; Yuan, Y.; Dale, B.E.; Gao, Z.; Jin, M. Mixing Alkali Pretreated and Acid Pretreated Biomass for Cellulosic Ethanol Production Featuring Reduced Chemical Use and Decreased Inhibitory Effect. Ind. Crops Prod. 2018, 124, 719-725. [CrossRef]

176. Neumann, P.; Pesante, S.; Venegas, M.; Vidal, G. Developments in Pre-Treatment Methods to Improve Anaerobic Digestion of Sewage Sludge. Rev. Environ. Sci. Biotechnol. 2016, 15, 173-211. [CrossRef]

177. Sharma, S.; Sharma, V.; Kuila, A. Thermochemical Pretreatment of Corn Husk and Enzymatic Hydrolysis Using Mixture of Different Cellulases. Biomass Convers. Biorefinery 2018, 8, 179-188. [CrossRef]

178. Paudel, S.R.; Banjara, S.P.; Choi, O.K.; Park, K.Y.; Kim, Y.M.; Lee, J.W. Pretreatment of Agricultural Biomass for Anaerobic Digestion: Current State and Challenges. Bioresour. Technol. 2017, 245, 1194-1205. [CrossRef]

179. Taherdanak, M.; Zilouei, H. Improving Biogas Production from Wheat Plant Using Alkaline Pretreatment. Fuel 2014, 115, 714-719. [CrossRef]

180. Kucharska, K.; Hołowacz, I.; Konopacka-Łyskawa, D.; Rybarczyk, P.; Kamiński, M. Key Issues in Modeling and Optimization of Lignocellulosic Biomass Fermentative Conversion to Gaseous Biofuels. Renew. Energy 2018, 129, 384-408. [CrossRef]

181. Abdul Aziz, N.I.H.; Hanafiah, M.M.; Mohamed Ali, M.Y. Sustainable Biogas Production from Agrowaste and Effluents-A Promising Step for Small-Scale Industry Income. Renew. Energy 2019, 132, 363-369. [CrossRef]

182. Kucharska, K.; Rybarczyk, P.; Hołowacz, I.; Łukajtis, R.; Glinka, M.; Kamiński, M. Pretreatment of Lignocellulosic Materials as Substrates for Fermentation Processes. Molecules 2018, 23, 2937. [CrossRef] 
183. Bolado-Rodríguez, S.; Toquero, C.; Martín-Juárez, J.; Travaini, R.; García-Encina, P.A. Effect of Thermal, Acid, Alkaline and Alkaline-Peroxide Pretreatments on the Biochemical Methane Potential and Kinetics of the Anaerobic Digestion of Wheat Straw and Sugarcane Bagasse. Bioresour. Technol. 2016, 201, 182-190. [CrossRef]

184. Łukajtis, R.; Rybarczyk, P.; Kucharska, K.; Konopacka-Łyskawa, D.; Słupek, E.; Wychodnik, K.; Kamiński, M. Optimization of Saccharification Conditions of Lignocellulosic Biomass under Alkaline Pre-Treatment and Enzymatic Hydrolysis. Energies 2018, 11, 886. [CrossRef]

185. Díaz-Trujillo, L.A.; Nápoles-Rivera, F. Optimization of Biogas Supply Chain in Mexico Considering Economic and Environmental Aspects. Renew. Energy 2019, 139, 1227-1240. [CrossRef]

186. Rieke, C.; Stollenwerk, D.; Dahmen, M.; Pieper, M. Modeling and Optimization of a Biogas Plant for a Demand-Driven Energy Supply. Energy 2018, 145, 657-664. [CrossRef]

187. Carlsson, M.; Lagerkvist, A.; Morgan-Sagastume, F. The Effects of Substrate Pre-Treatment on Anaerobic Digestion Systems: A Review. Waste Manag. 2012, 32, 1634-1650. [CrossRef]

188. Vasco-Correa, J.; Shah, A. Techno-Economic Bottlenecks of the Fungal Pretreatment of Lignocellulosic Biomass. Fermentation 2019, 5, 30. [CrossRef]

189. Baral, N.R.; Shah, A. Comparative Techno-Economic Analysis of Steam Explosion, Dilute Sulfuric Acid, Ammonia Fiber Explosion and Biological Pretreatments of Corn Stover. Bioresour. Technol. 2017, 232, 331-343. [CrossRef]

190. Brandt, K.L.; Gao, J.; Wang, J.; Wooley, R.J.; Wolcott, M. Techno-Economic Analysis of Forest Residue Conversion to Sugar Using Three-Stage Milling as Pretreatment. Front. Energy Res. 2018, 6, 1-11. [CrossRef]

191. Prasad, A.; Sotenko, M.; Blenkinsopp, T.; Coles, S.R. Life Cycle Assessment of Lignocellulosic Biomass Pretreatment Methods in Biofuel Production. Int. J. Life Cycle Assess. 2016, 21, 44-50. [CrossRef]

192. Safarian, S.; Unnthorsson, R. An Assessment of the Sustainability of Lignocellulosic Bioethanol Production from Wastes in Iceland. Energies 2018, 11, 1493. [CrossRef]

193. Soam, S.; Kapoor, M.; Kumar, R.; Gupta, R.P.; Puri, S.K.; Ramakumar, S.S.V. Life Cycle Assessment and Life Cycle Costing of Conventional and Modified Dilute Acid Pretreatment for Fuel Ethanol Production from Rice Straw in India. J. Clean. Prod. 2018, 197, 732-741. [CrossRef]

194. Rajendran, K.; Murthy, G.S. Techno-Economic and Life Cycle Assessments of Anaerobic Digestion-A Review. Biocatal. Agric. Biotechnol. 2019, 20, 101207. [CrossRef] 